\title{
The emerging role of water footprint in supply chain management: A critical literature synthesis and a hierarchical decision-making framework
}

\author{
Eirini Aivazidou ${ }^{\mathrm{a},{ }^{*}}$, Naoum Tsolakis $^{\mathrm{b}}$, Eleftherios lakovou ${ }^{\mathrm{c}}$, Dimitrios Vlachos $^{\mathrm{a}}$ \\ ${ }^{a}$ Laboratory of Statistics and Quantitative Analysis Methods, Industrial Management Division, Department of Mechanical \\ Engineering, Aristotle University of Thessaloniki, P.O. Box. 461, 54124 Thessaloniki, Greece \\ ${ }^{b}$ Centre for International Manufacturing, Institute for Manufacturing, Department of Engineering, University of Cambridge, \\ Cambridge CB3 OFS, United Kingdom \\ c Department of Engineering Technology and Industrial Distribution, Texas A\&M University, College Station, TX 77843-3367, \\ United States
}

\begin{abstract}
Freshwater overexploitation and scarcity have led to extensive shifts in demand patterns for waterfriendly products. As several agricultural and industrial activities are closely intertwined with water consumption, the availability of sufficient freshwater resources constitutes a significant precondition for covering global consumer needs. In this context, the design and management of sustainable supply chains in terms of freshwater resources' preservation have emerged as major challenges in the corporate agenda. As such, the concept of water footprint as a key performance indicator of freshwater utilization has been introduced at national, corporate and product levels. In this manuscript, we first provide a critical literature synthesis concerning product water footprint assessment in order to map the state-of-the-art research related to freshwater consumption and pollution in the agricultural and industrial sectors. Our analysis demonstrates that although water footprint assessment is a rapidly evolving research field, scientific publications focusing on a holistic approach concerning freshwater exploitation at a supply chain extent are rather limited. The findings further verify that the agrifood sector dominates global water use. In this respect, we analyse both corporate and academic literature in order to identify emerging issues on freshwater resources'
\end{abstract}

\footnotetext{
* Corresponding author. Tel: +30 2310 995896; fax: +30 2310996018.

E-mail address: aveirini@auth.gr (E. Aivazidou).
} 
management for agrifood products. Finally, we propose a first-effort hierarchical decision-making framework that includes water footprint mitigation policies for agrifood supply chains in order to support all stakeholders in developing a comprehensive water stewardship strategy.

Keywords: Water footprint assessment, supply chain management, literature synthesis, decisionmaking framework

\section{Introduction}

Except for the humanitarian perspective of freshwater resources, water is a pivotal constituent of major economic activities, including agricultural and industrial operations (Jefferies et al., 2012). According to statistics, the agricultural sector accounts for $70 \%$ of the global freshwater appropriation, while the industrial sector is responsible for $22 \%$ of the worldwide freshwater utilization (UN Water, 2009), allowing only $8 \%$ of freshwater resources for domestic use (WBSCD, 2006). However, there are several factors that pose significant stress over the availability of global freshwater supplies, such as growing world population, climate change and continuing industrialization (Manzardo et al., 2014). Moreover, changes in the production and consumption patterns due to rapid economic development, as well as the competition among water-dependent business sectors over freshwater appropriation, further influence the future of water resources (Ercin and Hoekstra, 2014).

As freshwater is depleting at an alarming rate, projections highlight that more than $40 \%$ of the world population will be living in regions facing severe water scarcity in 2050 (UN Water, 2014). In this regard, the identification, assessment and management of water-related risks have emerged as major concerns for companies, policy-makers and society (McKinsey and Company, 2009). Specifically, the European Union (2000) has enacted the Water Framework Directive (Directive $2000 / 60 / E C$ ), which is one of the most contemporary and advanced legislative frameworks for water protection worldwide (Hoekstra, 2011), in order to set targets to the member states concerning the preservation of freshwater resources. At the same time, the Union has funded research projects, 
such as E4WATER (2016) and EcoWater (2014), towards sustainable freshwater assessment and management in agriculture and industry. Indicatively, the EcoWater project aims at assessing the economic and environmental efficiency of various water-friendly practices in order to better support decision-making in diverse water use systems (Levidow et al., 2016). Regarding the business sector, empirical evidence clearly documents that not only have leading corporations integrated water stewardship into their corporate social responsibility agenda, but also they have fostered their profitability through water management initiatives (CDP, 2015).

In this perspective, the scientific community has developed the concept of water footprint (WF) as a key performance indicator of water use at national, corporate and product levels (Hoekstra et al., 2011). The term was initially introduced as a measure of freshwater resources' appropriation (Hoekstra and Hung, 2002) based on the theories of "ecological footprint" and "virtual water" developed by Wackernagel and Rees (1996) and Allan (1998), respectively. In particular, the WF of a product is defined as the total volume of freshwater consumed and polluted directly or indirectly across the product's entire supply chain (Hoekstra, 2008). As a multidimensional indicator, WF is comprised of three components, namely blue, green and grey water (Hoekstra et al., 2011). The blue water refers to the consumptive use of surface or groundwater, while the green water addresses the rain water stored in the soil and then absorbed by plants. Finally, grey water constitutes the amount of freshwater required for assimilating the load of pollutants given existing water quality standards. According to this approach, Hoekstra et al. (2011) developed the Water Footprint Assessment (WFA) methodology as a set of four discrete stages: (i) setting goal and scope, (ii) WF accounting, (iii) WF sustainability assessment, and (iv) WF response formulation. In particular, the first stage aims at determining the purpose of the study and the system boundaries. The second stage includes the collection of the necessary data and the calculation of the WF as a sum of the different water components, while the third stage focuses on the evaluation of water use from environmental, social and economic perspectives. The final stage embraces the identification of strategies and policies for WF mitigation. 
As opposed to WFA methodology, life cycle analysis (LCA) researchers have developed several alternative methodologies for the assessment of freshwater consumption and pollution (Kounina et al., 2013). Specifically, Ridoutt and Pfister (2010) propose a water-related LCA method based on the impact of freshwater utilization in relation to local water stress. In particular, the authors argue that green water does not contribute to water scarcity until it becomes blue water, while it is only accessible through the use of land. As such, the stressed-weighted WF is expressed as the total blue and grey water multiplied by the "water scarcity index" developed by Pfister at al. (2009). All scientific approaches for assessing WF impacts in a LCA context paved the way for the development of an international standard on water footprinting, namely ISO 14046 (ISO, 2014), which is considered as the water-oriented successor of the general LCA-based ISO 14040 and ISO 14044 (ISO, 2006). ISO 14046 specifies the principles, requirements and guidelines for the quantification, impact assessment and reporting of the WF of products, processes and organizations. Notably, the aforementioned standard can support decision-makers in identifying water risks, as well as management opportunities, in order to maximize water-related efficiency.

Notwithstanding scientific efforts in the field of water footprinting, several water accounting tools are relatively new or still underdeveloped (Christ, 2014), failing to address freshwater use and management holistically in a full supply chain context (Chico et al., 2013). In addition, industrial water management practices aim mainly at protecting local freshwater resources, with minor focus on recognising the related impact across supply chain networks (Northey et al., 2014). To that end, Quinteiro et al. (2014) emphasize the necessity of further research in order to determine actions for reducing the effects of consumptive and degradative freshwater utilization in the supply chain echelons that exhibit a dominant contribution to local water scarcity. In this respect, this work is a first research effort towards: (i) synthesizing the existing literature on product WF assessment in order to identify relevant gaps and opportunities, and (ii) mapping corporate WF management policies for supply chains, following the natural hierarchy of the decision-making process, in order to provide valuable managerial insights. The remainder of the paper is structured as follows. In Section 
2, we provide a critical synthesis of scientific publications focusing on product WF assessment in the agricultural and industrial sectors. In Section 3, we propose a comprehensive business-oriented hierarchical framework that includes WF mitigation decisions for agrifood supply chains as proposed by both academic and corporate communities. Finally, conclusions and recommendations for future research are discussed in Section 4.

\section{Water footprint assessment in the literature}

In this section, we first present the research methodology in order to provide a critical synthesis of the scientific literature on product WF assessment. The synthesis is followed by a brief discussion on the related results and findings in order to identify any gaps in the existing body of knowledge, as well as opportunities for prospective research.

\subsection{Research methodology}

According to Levi and Ellis (2006), a synthesis is a part of the literature review process that involves the combination of scientific publications for a specific topic into a whole. In practice, a synthesis aims at investigating methodological comparability and determining similarities and differences among studies with relevant subject, yet preserving the integrity of each research work and avoiding excessive details (Sandelowski et al., 1997). In this context, a literature synthesis contributes in summarizing and connecting the findings of multiple sources (Tranfield et al., 2003) in order to review a scientific area and provide valuable qualitative results, such as existing gaps, overlaps and opportunities for further research (lakovou et al., 2010).

Adopting this logic, we conduct a critical synthesis on product WF assessment during agricultural and/or industrial operations in order to map freshwater utilization in multiple production sectors from a supply chain perspective. This denotes that the literature synthesis focuses on articles that address freshwater consumption and pollution in various stages of a product's life cycle, expressed in units of freshwater volume per unit of mass or unit of product. As such, publications that mainly 
focus on the assessment of regional or national WFs, calculated in units of freshwater volume per unit of land area or year, are excluded from our analysis. The scope of the synthesis clearly differentiates our multisector supply chain-oriented research from a recent publication by Lovarelli et al. (2016), who comprehensively review the implementation of WF as an indicator of water use in crop productions at global or local extent. At the same time, several researchers quantify freshwater depletion as a part of inclusive LCA analyses across supply chains; Cellura et al. (2012) and Noya et al. (2015) in the agrifood sector, Huerta et al. (2016) in the livestock sector and Mirabella et al. (2014) in the furniture industry constitute indicative examples. However, as relevant publications deviate from giving emphasis on WF assessment as a standalone procedure, we have opted not to incorporate them into the synthesis.

As previously stated, the objective of this manuscript is to integrate WF assessment into supply chain management through synthesizing knowledge from peer-reviewed literature. To ensure a high scientific impact, the synthesis comprises articles retrieved from the Scopus and Web of Science databases as they offer a broad range of peer-reviewed journals in the fields of Natural Sciences and Engineering (Mongeon and Paul-Hus, 2016). To identify relevant papers, Boolean searches using appropriate keywords were carried out. In particular, the terms "water footprint assessment", "product water footprint", "freshwater consumption", "freshwater depletion", "freshwater pollution" and "water use" were searched either separately or in combination with the terms "supply chains" and "supply chain management". The authors utilized the "Article Title, Abstract, Keywords" and/or "Article Title" categories in Scopus, as well as the "Topic" and/or "Title" categories in Web of Science. In both databases, the timespan was set from "All years" to "Present". After a first check of the contents, collected articles were accepted or rejected in terms of further review. More specifically, the analysis was restricted to journal papers written in English that focus on product WF assessment. To increase consistency, all papers were counterchecked. After thorough reading, pertinent references cited in the papers were used as secondary sources for supplementing the literature synthesis. 
By May 31, 2016, a total of 74 articles concerning product WF assessment was identified. The annual allocation of the publications over the last nine years is depicted in Figure 1. Although the research period was not restricted, the first published case study is detected in 2008. In addition, a remarkably increasing number of product WF-oriented publications during the period 2012-2016 is documented, highlighting a growing interest in the field. Likewise, the distribution of the papers by journal is illustrated in Figure 2. Notably, collected journals cover a wide variety of scientific areas, such as environmental sustainability, LCA analysis, water resources' management and agricultural systems. Nevertheless, the distribution is quite uneven given that the "Journal of Cleaner Production" accounts for the vast majority of the articles included in the synthesis, indicating the dominant role of the journal in the rapidly advancing field of water footprinting.

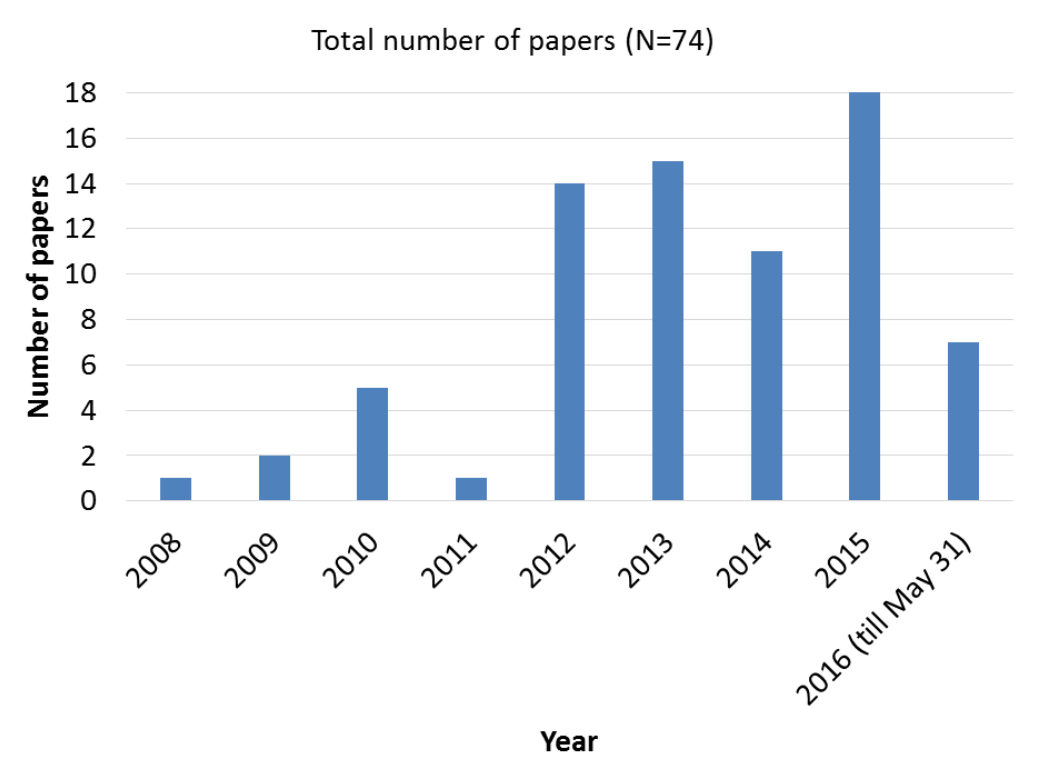

Figure 1. Distribution of publications per year. 


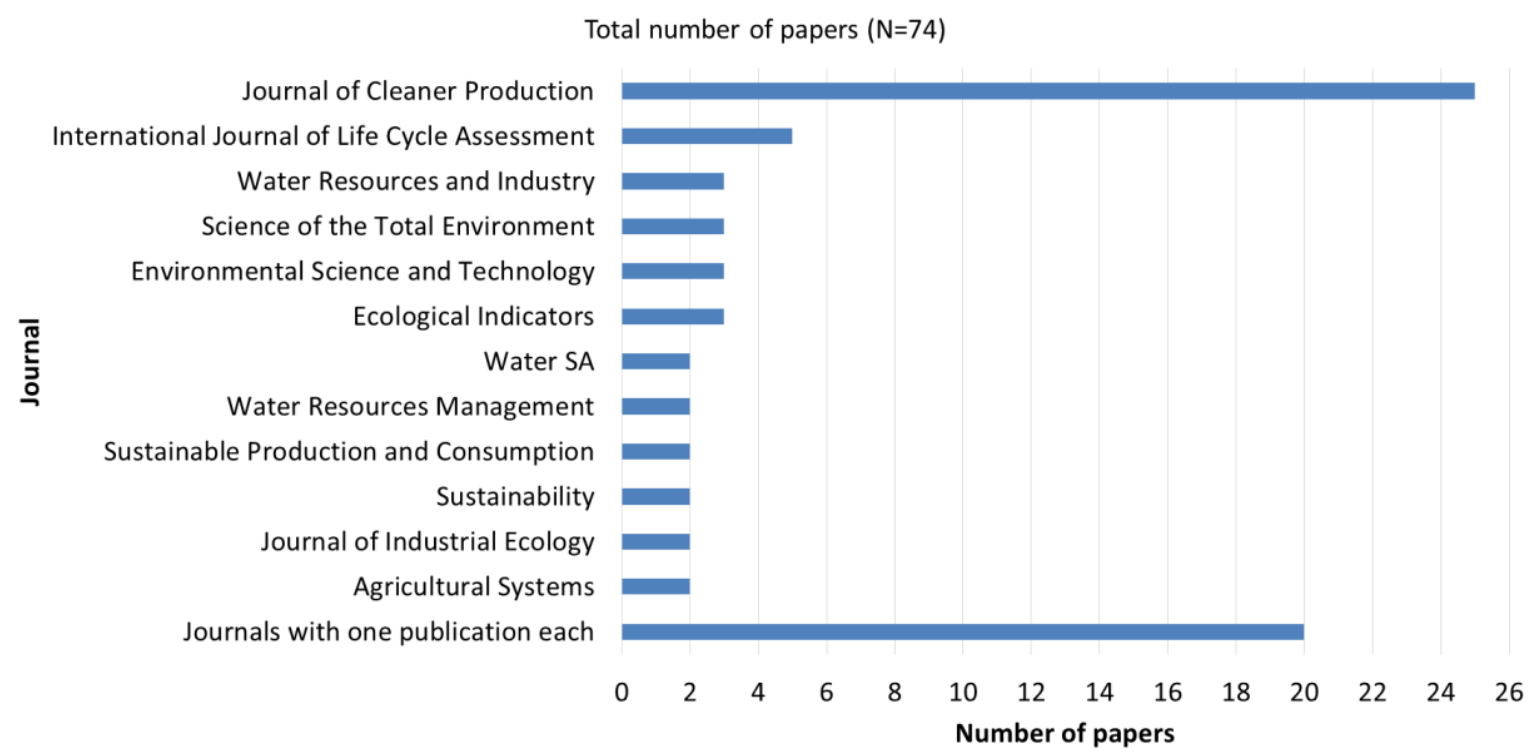

Figure 2. Distribution of publications per journal.

As a next step, all collected articles were systematically clustered according to the specific sector or industry that they refer to. Although the definition of the sectors was based on global economy standards, the final classification of the publications was performed at the discretion of the authors. Taking into consideration all research topics, we determined six sectors: agrifood, livestock and dairy, wine, biofuel and bioenergy, light industry, as well as heavy industry. More specifically, case studies on raw or possessed agricultural products were categorized into the agrifood sector. Notably, although livestock, dairy and wine industries could be incorporated into the agrifood sector, we opted to define them as separate sectors given the considerable number of publications documented at the respective industries. Furthermore, a plethora of studies focuses on supply chains of bioproducts, which are included in the biofuels and bioenergy sector. Papers concerning cosmetics and detergents, as well as textile and apparel production, were grouped into the light industry. In addition, articles regarding automotive, energy, pulp and paper, as well as steel and metal sectors, were integrated into the heavy industry category.

At the same time, detailed information of the selected publications (i.e. methodology, type of water use, supply chain echelon, country) was documented in order to obtain meaningful statistics. 
In particular, methodology refers to the WF assessment method used in each paper, while type of water use relates to the consumptive or degradative nature of product WFs. To establish the concept of water footprinting in a supply chain context, we thoroughly examined the system boundaries of the case studies for highlighting all supply chain stages considered for WF assessment. Specifically, seven discrete echelons of a typical supply chain, namely procurement, processing, packaging, transportation, retailing, consumer use and waste management, were documented. Additionally, information about the country of the studies assists in identifying the spatial dimension of freshwater utilization. Following all aforementioned steps of the proposed systemic research methodology, we then conducted the critical literature synthesis on the state-of-the-art research concerning product WF assessment in order to identify existing gaps, as well as opportunities for further research. In Figure 3, the research methodology steps are presented through the relevant flowchart. 


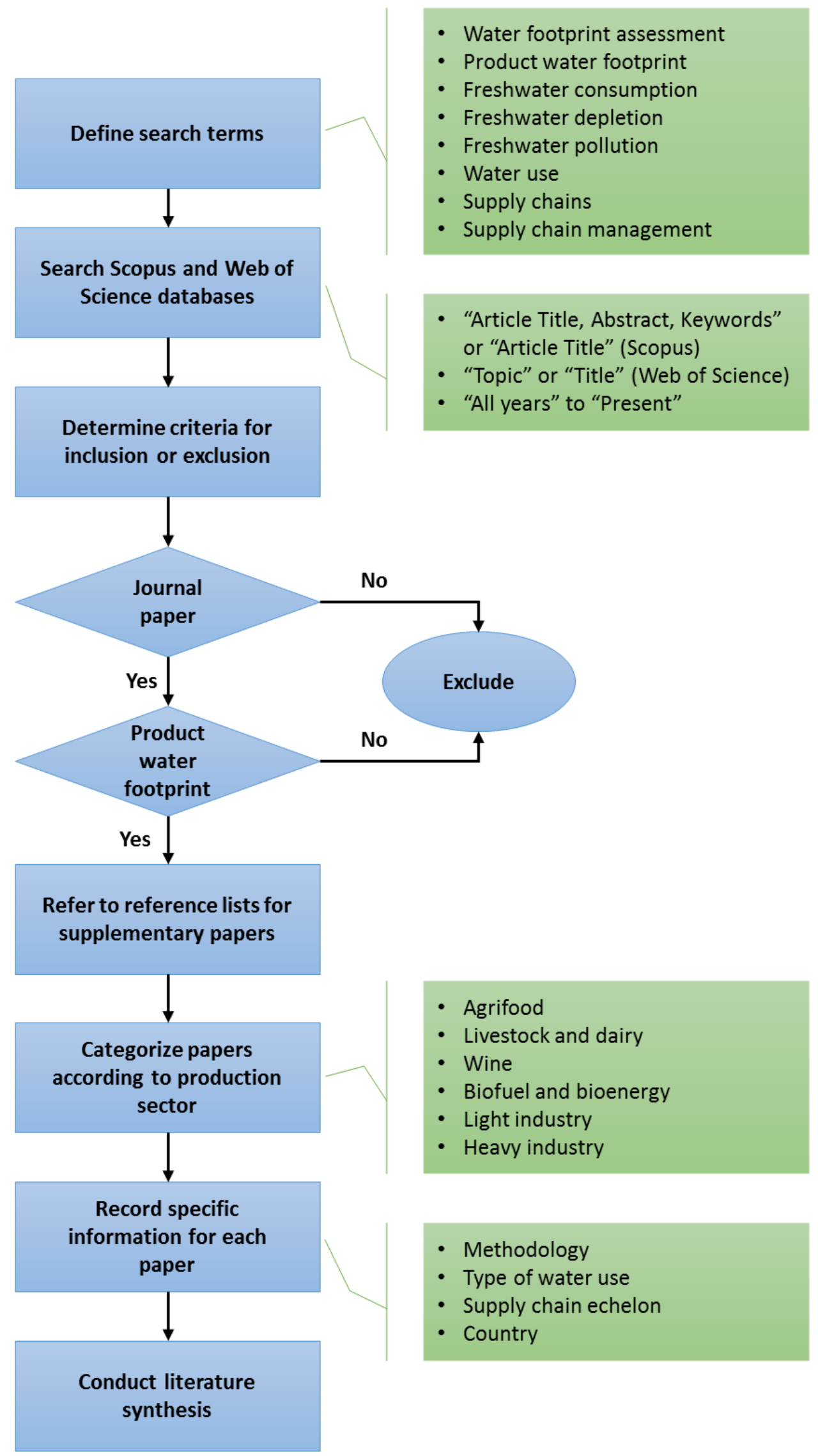

Figure 3. Flowchart of the research methodology. 


\subsection{Critical synthesis}

The critical synthesis of the selected literature on product WF assessment is presented as follows. The analysis focuses on the consumptive and degradative use of freshwater resources across supply chains in several production sectors. Table 1 summarizes the main results of the literature synthesis in a comprehensive manner.

\subsubsection{Water footprint of agrifood products}

Hess et al. (2015) and Rodriguez et al. (2015) quantify the WF of potato production in Great Britain and Argentina, respectively, in order to evaluate the relevant water-related supply chain risks. Both publications reveal that high irrigation requirements increase blue water consumption, whereas the latter study considers fertilizer utilization as a major contributor to freshwater pollution. According to the results, the stress-weighted blue water of the British potatoes equals to 11 cubic metres $\left(\mathrm{m}^{3}\right.$ ) per tonne (t) (Hess et al., 2015), while the total green, blue and grey WF of the Argentinian potatoes is $324 \mathrm{~m}^{3}$ per $\mathrm{t}$ (Rodriguez et al., 2015). However, the results are not comparable due to the different assessment methodologies used; Hess et al. (2015) combine multiple assessment methods in contrast to Rodriguez et al. (2015) that utilize the WFA manual.

Several scientific efforts conduct both carbon and WF assessment across the life cycles of fresh domestic (Page et al., 2012) and imported (Payen et al., 2015) tomatoes, as well as dried tomatoes (Ramírez et al., 2015). According to LCA-based approaches, the blue WF of the tomato supply chain in Australia ranges from 5 to 50 litres (L) per kilogram (kg) of fresh product (Page et al. 2012), while the freshwater use of tomatoes produced in unheated greenhouses in Morocco and consumed in France equals to $28 \mathrm{~L}$ of water equivalent per kg of tomatoes (Payen et al., 2015). In addition, Payen et al. (2015) compare the obtained results with those concerning tomato production in French heated greenhouses. Although the WF of one $\mathrm{kg}$ of French tomatoes is lower (7.5 L of water equivalent), Moroccan tomato production results in lower energy consumption, greenhouse gas emissions and freshwater eutrophication. According to Ramírez et al. (2015), the WF of one kg of 
dried tomatoes in Germany is $51 \mathrm{~L}$ in case cultivation and drying phases are concurrent, as well as 91 $\mathrm{L}$ when the two phases are taking place in different locations.

Furthermore, Schäfer and Blanke (2012) and Stoessel et al. (2012) calculate both carbon emissions and water use during the production of several fresh agricultural commodities. According to the WFA method, the blue WF of one kg of pumpkins produced in Argentina and consumed in Germany ranges from 0.4 to $9 \mathrm{~L}$ of water (Schäfer and Blanke, 2012). Notably, the authors support Page et al. (2012) who argue that freshwater utilization is closely related to the production system used. Conversely, Stoessel et al. (2012) apply a LCA methodology to assess the WF of several fruits and vegetables of two major Swiss retailers. The agricultural products are either produced locally or sourced from foreign countries. The outcomes of the study imply that the impact of water consumption depends on the location of agricultural production. Despite of the methodological approach used, all aforementioned studies indicate that greenhouse gas emissions have more severe ramifications than freshwater consumption.

Following the previous study of Hess et al. (2015), Hess et al. (2016) quantify both the blue water scarcity footprint and greenhouse gas emissions per typical portion of three starchy carbohydrate foods in the UK, namely British fresh potatoes, Italian dried pasta and Indian dried basmati rice. Unlike Hess et al. (2015) that focus only on the agricultural production, Hess et al. (2016) consider the assessment of WF across entire supply chains, following a LCA-based methodology. As basmati rice requires significant amounts of irrigated water, it has considerably higher blue WF compared to potatoes and pasta that are mainly rain-fed crops. In particular, the stress-weighted blue water consumption of British potatoes and Italian pasta are low (0.6 and $1.8 \mathrm{~L}$ of water equivalent per portion, respectively), while that of Indian basmati is two orders of magnitude greater (160 L of water equivalent per portion).

Almeida et al. (2014) utilize ISO 14040 and ISO 14044 in order to study a small-scale tomato production in a greenhouse located in Northern Italy. In terms of WF, the results show that the total 
consumptive and degradative WF equals to $123 \mathrm{~L}$ per kg of fresh tomatoes. At the same time, Brodt et al. (2013) apply ISO 14040 to assess the environmental impacts of tomato paste and canned diced tomatoes in Michigan, USA, during the cultivation, processing, packaging and transportation stages. The authors conclude that organic systems for tomato cultivation are more water-efficient than conventional systems. Additionally, a sensitivity analysis reveals that in case organic tomato yield decreases by $30 \%$, the water used to produce a unit of diced tomatoes and paste increases by $38 \%$ and $41 \%$, respectively.

More recently, based on the ISO 14040 and ISO 14044 guidelines, Jeswani et al. (2015) conduct a WF assessment of breakfast cereals manufactured by Kelogg Europe through exploring the environmental sustainability in the food-energy-water nexus. Using indicators provided by the WFA and a LCA-based methodology, the study reveals that the blue and green water of cereals are estimated at 672 and 1,100 L per kg of product, respectively. Furthermore, the life cycle WF of cereals is equal to 283 equivalent $\mathrm{L}$ per $\mathrm{kg}$ when consumption is neglected contrary to 311 equivalent $\mathrm{L}$ per $\mathrm{kg}$ in case consumption with milk is included in the assessment process. Notably, the cultivation echelon is responsible for more than $90 \%$ of the water consumption across the cereal supply chain. Moreover, the authors calculate the impact of cereal production to freshwater pollution expressed as eutrophication.

Ridoutt et al. (2010) assess freshwater consumption and pollution of the fresh mango supply chain in Australia using a LCA technique. In contrast to all relevant studies, this research constitutes a novel effort in mapping the WF of food losses. In particular, although the WF during the agricultural stage equals to $2,298 \mathrm{~L}$ per $\mathrm{kg}$ of mango, the total WF rises to 5,218 L per $\mathrm{kg}$ of fresh product when food waste during transportation, retailing and consumption stages is considered. Motivated by the economic significance of banana production to the economy of Ecuador, Roibás et al. (2015) investigate the sustainability of bananas grown in several organic or conventional plantations. Based on the WFA method, the authors calculate the environmental impact per kg of 
Ecuadorian bananas consumed in Spain, from a cradle-to-grave perspective, and calculate that the total green, blue and grey WF of bananas is $484 \mathrm{~L}$ per $\mathrm{kg}$ of product at the consumption stage. Notably, although WF calculation methods and cultivation regions of mangos (Ridoutt et al., 2010), bananas (Roibás et al., 2015) and pumpkins (Schäfer and Blanke, 2012) differ considerably, mango may be significantly less water friendly than other fresh fruits.

Milà i Canals et al. (2010) investigate six case studies related to the UK consumption of broccoli produced in the UK and Spain. The provided LCA-based approach assists in comparing the WF of an irrigated crop in a water-scarce region with a rain-fed crop in a water-abundant region. The study results indicate that broccolis produced in the UK have lower water-related impacts than broccolis imported from Spain. In addition, while the majority of water use in Spain refers to irrigation, the study further reveals other important WF hotspots related to water use during cooking and electricity production. Moreover, de Figueirêdo et al. (2014) study the life cycle of Brazilian exported yellow melons and quantify freshwater consumption. The findings of the implemented LCA approach indicate that the average water consumption throughout the life cycle of yellow melons is $198 \mathrm{~L}$ per kg of exported melons. In the same vein as other research efforts for broccoli (Milà i Canals et al., 2010), tomato (Almeida et al., 2014) and cereals (Jeswani et al., 2015) production, the study supports that water availability impact is mainly attributed to water consumption from irrigation operations.

Ridoutt et al. (2009) and Manzardo et al. (2016) assess the WF during the life cycle of tomato sauces in Australia and the USA, respectively. Based on a carbon footprinting methodology, the total WF of the Australian tomato sauce is $202 \mathrm{~L}$ per jar, dominated by blue and grey water (Ridoutt et al., 2009). For comparison reasons, the authors calculate the WF of peanut candies, which is $1,153 \mathrm{~L}$ per package, dominated by green water. Comparing the WFA and ISO 14046 techniques, Manzardo et al. (2016) argue that both methods provide approximately the same results concerning the freshwater consumption hotspots across the tomato sauce supply chain in the USA. However, the methods are 
rather inconsistent regarding freshwater pollution hotspots. Nevertheless, the main focus of this paper is the WF evaluation of two alternative packages, a glass and a carton one. Although both methodologies consider the two packages as equivalent in terms of consumptive water use, the results vary in terms of degradative water use.

Except for Manzardo et al. (2016), previous research has been conducted for quantifying the blue and green WFs of tea and margarine supply chains through implementing both the WFA approach and a LCA-based method (Jefferies et al., 2012). According to the WFA results, the freshwater consumption of a $50 \mathrm{gr}$ carton of tea is $294 \mathrm{~L}$ of green water and $10 \mathrm{~L}$ of blue water, whereas that of a $500 \mathrm{gr}$ tub of margarine is $553 \mathrm{~L}$ of green water and $109 \mathrm{~L}$ of blue water. Concerning the LCA results, the blue WFs per unit of final product are $13 \mathrm{~L}$ for tea and $114 \mathrm{~L}$ for margarine. Although both methods have the potential for a cradle-to-grave analysis, the variability of the results derives from the different system boundaries of the two methods.

Muhamad et al. (2014) and Suttayakul et al. (2016) quantify the freshwater consumption and degradation of oil palm plantations using the WFA methodology. Muhamad et al. (2014) calculate the total volumetric WF that is associated with the production of oil palm seedlings in Malaysia, including cultivation, packaging and transportation. The total blue WF equals to $0.157 \mathrm{~m}^{3}$ per $\mathrm{t}$ of fresh fruit bunch, mainly due to high volumes of irrigation water consumed. The green and grey WFs are 0.31 and $0.00183 \mathrm{~m}^{3}$ per $\mathrm{t}$ of fresh fruit bunch, respectively, indicating that the volume of polluted water during the production of oil palm seedlings is minimal. Focusing on the palm oil plantations and mills in Thailand, Suttayakul et al. (2016) evaluate the WF of the total production of fruit bunches and crude palm oil. The average WF of fruit bunches is $1,063 \mathrm{~m}^{3}$ per $\mathrm{t}$, from which $68 \%$, $18 \%$ and $14 \%$ constitute the green, blue, and grey water, respectively. Considering all mills, the average $W F$ for producing a t of crude palm oil is estimated to be $5,083 \mathrm{~m}^{3}$.

At the same time, Tran et al. (2015) quantify the energy use, water use and greenhouse gas emissions of cassava starch production mainly used for food. Specifically, the authors assess the 
environmental impact of two small-scale starch extraction technologies in Vietnam and Colombia and a large-scale one in Thailand. Freshwater use in Vietnam and Colombia equals to 36 and $62 \mathrm{~m}^{3}$ per $t$ of starch, respectively. The observed deviation in freshwater consumption is attributed to the fact that surface water is abundant in Colombia, while pumping of groundwater from boreholes is required in Vietnam. On the other hand, the large-scale technology consumes a net water volume of $9.8 \mathrm{~m}^{3}$ per $\mathrm{t}$ of starch owing to water recycling practises.

Ercin et al. (2011) conduct a pilot study to assess the WF of a sugar-containing carbonated beverage produced in the Netherlands using raw materials, such as sugar beet, sugar cane and high fructose maize syrup, sourced from different countries. The authors utilize the WFA methodology in order to provide detailed calculations of the consumptive and degradative water use from a cradleto-grave perspective. The total WF of a $0.5 \mathrm{~L}$ PET-bottle of beverage equals to $169 \mathrm{~L}$ (using sugar beet from the Netherlands) and $309 \mathrm{~L}$ (using sugar cane from Cuba). Notably, the supply chain WF constitutes $99.8 \%$ of the total water use, while the operational WF, which is the direct volume of water incorporated into the product, is estimated at $0.5 \mathrm{~L}$ per unit of product. In an ensuing study, Ercin et al. (2012) quantify the WFs of soymilk produced in Belgium and soy burger processed in the Netherlands and compare them with the WFs of cow's milk and beef burger. The authors analyse the resulting WFs of organic and non-organic soybean farms in Canada, China and France where soybeans are imported from. Main findings indicate that the total WFs of one L of soymilk and $150 \mathrm{gr}$ of soy burger are 297 and 158 L, respectively, while the major volume of the total WF occurs during the farming stage of the products' ingredients.

Aldaya and Hoekstra (2010) provide a seminal work about the WF of pasta and pizza margherita in Italy. Their calculations are based on the WFA manual and indicate that the total WF for the production of one $\mathrm{kg}$ of traditional pasta is $1,924 \mathrm{~L}$ and of a $0.725 \mathrm{~kg}$ pizza margherita is $1,216 \mathrm{~L}$. Additionally, Ruini et al. (2013) study the WF of Barilla's pasta supply chain and provide a range for the related WF further validating the findings of Aldaya and Hoekstra (2010). Particularly, following 
the ISO 14040 guidelines and using the WFA method, the authors find that the WF of one kg of Barilla pasta ranges between 1,336 and $2,847 \mathrm{~L}$ of water, depending on the production site, local environmental conditions and agricultural techniques used to cultivate durum wheat. Moreover, Antonelli and Ruini (2015) apply the WFA method and find that the WF of dry semolina pasta along the supply chain of Barilla is significantly lower accounting for $1,292 \mathrm{~L} \mathrm{per} \mathrm{kg}$. Any minor differences are attributed to the spatial characteristics of the regions where the pasta raw materials are cultivated. Specifically, Aldaya and Hoekstra (2010) consider the WF for durum wheat cultivated in the dry regions of Puglia and Sicily, Italy, whereas Antonelli and Ruini (2015) report that durum wheat for the pasta assessed is mainly supplied by mills located in five foreign countries where water reuse projects have been applied.

\subsubsection{Water footprint of livestock and dairy products}

Ridoutt et al. (2012a) study the freshwater consumption across a lamb meat supply chain, spanning from meat production in Australia to household consumption in the USA. Following Ridoutt et al. (2010), the current analysis includes WFs related to food waste during distribution, retailing and consumption. Based on a water-stress LCA methodology, the normalized WF of lamb meat equals to $44 \mathrm{~L}$ of water equivalent per $\mathrm{kg}$. The authors conclude that meat products can be considered as more water friendly compared to other agricultural products, such as cereals. Furthermore, the WF of meat products is strongly influenced by location and breeding system of the livestock. In the same vein, Ridoutt et al. (2012b) apply the same methodology extending their previous research towards water use in six beef cattle production systems in Australia. The livestock production systems are diverse in terms of farm practice, product type and local water stress. The normalised WF ranges from 3.3 to $221 \mathrm{~L}$ of water equivalent per $\mathrm{kg}$ of live weight at farm gate. Contrary to their previous findings (Ridoutt et al., 2012a), Ridoutt et al. (2012b) argue that the WF of the beef cattle production systems under study is quite similar to the WF of main cereal products cultivated in the same region. 
In contrast to the LCA approach, several publications quantify both consumptive and detractive water use of several livestock products, including pork (de Miguel et al., 2015), poultry and beef (Gerbens-Leenes et al., 2013) and sheep and goat (Mekonnen and Hoekstra, 2012) meat, based in the WFA methodology. In particular, de Miguel et al. (2015) evaluate the WF of four different pig production systems in Spain and conclude that the average WF is estimated at 3,765 $\mathrm{m}^{3}$ per $\mathrm{t}$ of pork meat. The significant variability of the results provided by Ridoutt et al. (2012a) for lamp, Ridoutt et al. (2012b) for beef and de Miguel et al. (2015) for pork meat is attributed to the different accounting methods; de Miguel et al. (2015) measure the actual water volumes consumed or polluted, while both Ridoutt et al. (2012a) and Ridoutt et al. (2012b) use normalized WF values to express the impact of water use on a regional setting. Likewise, Mekonnen and Hoekstra (2012) provide a detailed estimate of the WF of eight farm animals and animal products for three production systems (i.e. grazing, mixed and industrial) in several countries. For the case of pigs, the authors calculate a global average WF of $3,831 \mathrm{~m}^{3}$ per $\mathrm{t}$, which is quite similar to the respective results provided by de Miguel et al. (2015). The findings also show that animal products from grazing systems have lower blue and grey WFs than those from industrial systems. In addition, the average WF per calorie for beef is 20 times larger than for cereals and starchy roots, while the WF per gram of protein for milk, eggs and chicken meat is 1.5 times larger than for pulses. Gerbens-Leenes et al. (2013) explore the factors influencing the WF of meat and consider differences between poultry, pork and beef among production systems in different countries. The authors identify three main factors affecting the WFs of meat, namely food conversion efficiency, animals' feed composition and origin of the feed. Moreover, Gerbens-Leenes et al. (2013) verify the results provided by Mekonnen and Hoekstra (2012) and conclude that industrial systems have the highest blue and grey WFs especially for beef, while grazing systems have the lowest blue and grey WFs.

Considering both greenhouse gas emissions and water use, Noya et al. (2016) perform a cradleto-gate analysis in order to quantify carbon and WFs along the supply chain of eight different types of pork products. Despite the fact that the study is based on the ISO 14040 guidelines, freshwater 
consumption and pollution are calculated according to the WFA methodology. Indicatively, the total WF of ham and sausage equals to 9.1 and $15.6 \mathrm{~m}^{3}$ per $\mathrm{kg}$ of final product, respectively. Regarding water components, feed production accounts for the main part of green water, pork processing has a critical role in blue water, while cleansing activities contribute to grey water. The increased WF compared to the results of Mekonnen and Hoekstra (2012) and de Miguel et al. (2015) is reasonable due to the inclusion of more supply chain stages in the analysis.

Motivated by the significant WF volumes related to meat production, Miglietta et al. (2015) investigate the WF of two species of edible insects, which have already been commercially produced in Western countries as an alternative source of protein. Based on the WFA approach, the authors calculate that the WFs of farmed "Tenebrio molitor" and "Zophobas morio" mealworms equal to 3,930 and $4,752 \mathrm{~m}^{3}$ per $\mathrm{t}$, respectively. These WF volumes are higher than those for meat production provided by de Miguel et al. (2015) and Mekonnen and Hoekstra (2012). However, in case the WF of mealworms is expressed in L per gr of protein, then the resulting ratio equals to 23 . Surprisingly, the respective ratio for chicken is 34 and that of beef is 112 . The authors conclude that adopting a diet based on insects can contribute to a more sustainable way of feeding the growing human population.

In the field of dairy products, Drastig et al. (2010) present a calculation of the blue WF for milk production in Germany. The authors observe a decreasing demand for direct blue WF during milk production due to decreasing animal numbers and improved feeding practises that both result in increased average milk yield per cow. Overall, the average blue water consumption is approximately $4 \mathrm{~L}$ per kg of milk mainly attributed to water consumed to produce feed for the cows. In addition, de Boer et al. (2013) evaluate the environmental impact of freshwater consumption, including resource depletion, along the global supply chain of milk production in the Netherlands, following a LCAbased approach. The authors conclude that the consumptive water use for the production of one $\mathrm{kg}$ of fat-and-protein corrected milk in the Netherlands equals to 66 L. Particularly, irrigation during 
roughage cultivation accounts for $76 \%$ of the total WF, production of concentrates is responsible for $15 \%$, while drinking and cleaning services contribute by $8 \%$. Transportation, as well as the production of diesel, electricity and fertilisers, refers to $1 \%$ of the total water consumption.

More recently, Palhares and Pezzopane (2015) calculate the WF of a conventional and an organic milk production system in Brazil with special focus on the farming stage. Based on the WFA methodology, green water is the main contributor to the total water use, while approximately $95 \%$ of blue water refers to irrigation in both conventional and organic systems. As regards freshwater pollution, organic milk accounts for a greater grey water than conventional milk. On the other hand, Huang et al. (2014) provide a more comprehensive analysis of the water use across the supply chains of fresh milk and a milk chocolate in China. The authors use a LCA-based approach in order to compare the WF of Chinese products with relevant products imported from the USA and New Zealand. According to the results, the WFs of Chinese milk and milk chocolate are significantly lower than those from the USA yet little higher than those from New Zealand. From a life cycle perspective, freshwater use during milk production accounts for more than $98 \%$ of the total WF in China and the USA, whereas industrial processing is responsible for more than $80 \%$ in the total WF in New Zealand. To compare the WFA with several LCA-based approaches, Zonderland-Thomassen and Ledgard (2012) assess the WF of two different dairy farming systems in New Zealand and evaluate the suitability of indicators derived from each WF assessment method. However, the results demonstrate significant differences due to: (i) the impact on freshwater availability in relation to land conversion from native vegetation to agriculture, (ii) the application of different characterisation factors, and (iii) the implementation of the normalisation procedure.

\subsubsection{Water footprint of wine}

Based on the WFA manual, Ene et al. (2013) calculate the average WF of a wine supply chain in Romania. According to the findings, the WF of a $0.75 \mathrm{~L}$ bottle of wine is approximately $1,754 \mathrm{~L}$, depending on weather conditions and types of grapes, out of which $82 \%$ is green, $3 \%$ is blue and 
$15 \%$ is grey water. In particular, $99 \%$ of the total WF is related to the supply chain freshwater use, while the remaining $1 \%$ is associated to the operational freshwater utilization within the plant. To a further extent, Lamastra et al. (2014) propose a new WF assessment approach focusing in detail to the calculation of the grey WF. The authors implement both the new methodology and the WFA method in the cases of six different wine types of the same winery in Sicily, Italy. The study results indicate that the green WF of wines ranges between 705 and $916 \mathrm{~L}$ per $\mathrm{L}$ of wine. Furthermore, for all types of wine the blue water volume is approximately $2 L$ per $L$ of wine, accounting for less than $0.5 \%$ of the total WF. In addition, the grey WF equals to $156 \mathrm{~L}$ per $\mathrm{L}$ of wine for diluting pollution due to fertilizers and pesticides.

Based on the ISO 14046, Bonamente et al. (2015) quantify the direct green, blue and grey WFs of a typical red wine produced from a blend of grape varieties by a medium-size winery in Umbria, Italy. Applying the Lamastra et al. (2014) method, the authors calculate the WF of a $0.75 \mathrm{~L}$ bottle of wine which equals to $632 \mathrm{~L}$. Moreover, the findings indicate that the major WF contribution is attributed to green water (98\%). Contrary to the case of Romanian wines (Ene et al., 2013), the WFs of both Central Italian (Bonamente et al., 2015) and South Italian (Lamastra et al., 2014) wines are rather similar, highlighting the spatial dimension of water use. In a following study, Bonamente et al. (2016) perform a combined carbon and WF assessment across the supply chain of the aforementioned Italian red wine using the same dataset. Though applying three complementary LCA-based approaches, the total WF of a $0.75 \mathrm{~L}$ wine bottle is calculated to be $578 \mathrm{~L}$, while the upstream supply chain operations (i.e. viticulture and procurement) account for $95 \%$ of the total water use. Although Bonamente et al. (2016) further evaluate indirect water use, the total WF is decreased compared to the results of Bonamente et al. (2015) due to methodological improvements and the use of updated water-related databases.

Herath et al. (2013a) combine a LCA-based approach with a hydrological water-balance technique in order to quantify the consumptive and degradative water use for wine production in two 
Australian regions. The results show that freshwater consumption across the wine life cycle is 742.5 and $667 \mathrm{~L}$ per bottle for the regions of Marlborough and Gisborne, respectively, while freshwater pollution equals to 40 and $188 \mathrm{~L}$ per bottle for each specific region. Although the blue water during viticulture is naturally recharged, the consumptive WF at the winery stage is rather small compared to the WF at the vineyard stage. In an ensuing study, Herath et al. (2013b) extend their research on the WF quantification of wine through comparing the results obtained using several methodologies, further including the WFA method, in order to document freshwater utilization from different perspectives. At the same time, Quinteiro et al. (2014) apply various water-related LCA methodologies in order to identify the WF hotspots of a wine supply chain in Portugal. Although all methods, except one that considers land use effects, result in equal blue water volumes, there is a noteworthy variability concerning the identification of the dominant activities in terms of water use.

\subsubsection{Water footprint of biofuels and bioenergy}

As biofuel crops compete with food crops for land and freshwater use, several scientific publications address freshwater consumption and pollution during biofuel production (GerbensLeenes and Hoekstra, 2012), further including transportation (Mangmeechai and Pavasant, 2013). Specifically, Gerbens-Leenes and Hoekstra (2012) assess the green, blue and grey WF of agricultural crops in Ukraine, India and Pakistan for the production of bioethanol using the WFA methodology. According to the results, the average WFs of sugar cane, sugar beet and maize are 209, 133 and $1,222 \mathrm{~m}^{3}$ per $\mathrm{t}$ of crop, respectively. However, taking into account the factors to convert crop WFs to bioethanol WFs, maize is generally more preferable as feedstock for bioethanol than sugar beet or sugar cane. Similarly, Mangmeechai and Pavasant (2013) quantify direct and indirect WFs associated with the production of molasses and cassava-based ethanol in Thailand. Based on the WFA method, the authors calculate both consumptive and degradative water use during cultivation, processing and transportation of raw materials and fuels. The findings indicate that the WF of molasses-based ethanol ranges between 1,510 and 1,990 L per $L$ of bioethanol, while the WF of cassava-based 
ethanol varies between 2,300 and 2,820 L per L of bioethanol. Notably, the fact that $99 \%$ of freshwater consumption and pollution occurs during the cultivation stage verifies the emphasis given by Gerbens-Leenes and Hoekstra (2012) to the agricultural stage.

Furthermore, Hagman et al. (2013) calculate freshwater consumption during the farming, processing and usage stages of jatropha-based biofuel in Mozambique using both the WFA manual and other LCA approaches. Comparing the results with the WF of fossil fuel imported from Libya, the total volumetric blue and green WF of the produced biofuel is greater than that of fossil diesel given that the latter accounts for zero green water consumption. However, the stress-weighted blue WF of jatropha biofuel is lower compared to that of fossil fuel due to low water scarcity in Mozambique. Su et al. (2015) and Chiu et al. (2015) assess the WF during the production of first-generation and second-generation bioethanol in Taiwan, respectively. Both studies apply the WFA methodology, while the use phase is excluded from the analyses. According to the research findings, the WF of edible rice can be higher than the WF of first-generation bioethanol produced from specific energy crops (Su et al., 2015). On the contrary, second-generation bioethanol demonstrates substantially lower WF than first-generation bioethanol given that a large part of the raw materials of secondgeneration biofuels has already been accounted during their first use (Chiu et al., 2015).

Contrary to the WFA approach, Fingerman et al. (2010) provide an agro-climatic LCA-based model and propose a list of quantitative metrics to enable rigorous analysis of water impacts related to bioethanol production from sustainable feedstocks in California, USA. The findings indicate that freshwater requirements for the production of bioethanol range from 500 to $3,500 \mathrm{~L}$ per $\mathrm{L}$ of biofuel. The authors juxtapose the results with the WF of a comparable -in terms of energy content- volume of gasoline, which is significantly lower ranging from 2 to 14 L. King and Webber (2008) further elaborate that fossil fuels consume less water than biofuels. In particular, the authors investigate the water intensity for a light duty vehicle travel in the USA using fuels based upon petroleum, natural gas, unconventional fossil fuels, hydrogen, electricity and two biofuels (i.e. corn bioethanol and soy 
biodiesel). According to the results, the lowest water consumptive rates (less than 0.15 gallons of water per mile) are documented when using conventional petroleum-based fuels, non-irrigated biofuels, hydrogen from methane or electrolysis via renewable electricity, as well as electricity from non-thermal renewable sources.

As opposed to crop-based biofuels, Batan et al. (2013) are the first to assess the WF of biofuels derived from microalgae in ten USA locations, considering geographic and climatic variations. The authors elaborate a hybrid LCA-based method and calculate the blue and green WFs during cultivation, as well as the net life cycle WF during processing and transportation, of four different microalgae biofuels. Specifically, the total blue and green WF varies from 18 to $82 \mathrm{~m}^{3}$ per gigajoule (GJ), while the lifecycle WF ranges between 21 and $83 \mathrm{~m}^{3}$ per GJ. Moreover, the results show that microalgae biofuels have an equivalent or even lower WF to most types of biomass and oilseedbased biodiesel.

In the bioenergy sector, Gerbens-Leenes et al. (2009) evaluate the WF per unit of energy derived from biomass and then provide a comparative analysis of the WF for several conventional and renewable energy carriers. Indicatively, the WF of average bioenergy ranges from 24 to $143 \mathrm{~m}^{3}$ per GJ depending on the origin of biomass. On the contrary, the WFs of uranium, natural gas, coal and crude oil equal to $0.1,0.1,0.2$ and $1.1 \mathrm{~m}^{3}$ per GJ, respectively. Notably, renewable energy carriers exhibit significant differences regarding WFs: wind energy (negligible), solar thermal energy $\left(0.3 \mathrm{~m}^{3}\right.$ per GJ) and hydropower ( $22 \mathrm{~m}^{3}$ per GJ). As biofuels are more water intensive that other fuel types (Fingerman et al., 2010), except for non-irrigated biofuels (King and Webber, 2008), the findings indicate that the WF of bioenergy is likewise 70 to 400 times larger than the WFs of the rest primary energy carriers, excluding hydropower.

\subsubsection{Water footprint of light industry products}

Chico et al. (2013) and Joa et al. (2014) evaluate the WF of various textile products during the agricultural and processing stages. Following the WFA methodology, Chico et al. (2013) analyse the 
WF of trousers produced in Spain from cotton and wood-based fabrics. In both cases, cultivation stage is the major WF hotspot, while freshwater consumption and pollution during the industrial phase differ according to the type of fabric and processing method. In general, wood-based jeans are more water-friendly than cotton jeans, accounting for 1,454 and $3,233 \mathrm{~m}^{3}$ of water per item, respectively. In contrast, Joa et al. (2014) develop a novel approach for corporate water accounting in order to overcome the methodological gaps of the WFA and LCA techniques. The proposed methodology is implemented in the case of WF assessment across a global cotton textile chain. The results reveal that although freshwater consumption during the raw materials' stage is the major WF hotspot, manufacturing is also considered as a critical contributor to the total water use.

Based on their own developed methodologies, Wang et al. (2013) and Chen et al. (2015) further calculate water use in the textile and fabric sectors. Specifically, Wang et al. (2013) study the industrial WF of seven knitted fabrics of a textile industry in China. However, no detailed WF calculations are provided and the results are rather presented as ratios of blue and grey WFs to the total water use per product. Contrary to the findings provided by Chico et al. (2013), the authors argue that dyeing is the major WF hotspot in the textile industry, followed by bleaching, washing and drying. Particularly, these processes account for more than 95\% of each fabric's WF. However, Wang et al. (2013) do not consider the cultivation stage of cotton in their calculations. At the same time, Chen et al. (2015) criticise the existing WF assessment methodologies concerning industrial processing, identify the defective points of current water accounting methods and propose a new tool for evaluating direct and indirect water use of industrial products. The developed methodology is applied in two typical products of the textile industry, namely a screen printing fabric and a digital printing fabric. The analysis is based on production data provided by a printing and dyeing company in Eastern China, while the results indicate that the average water withdrawal per metre $(\mathrm{m})$ of screen printing fabric is 5.4 times as that of digital printing fabric. 
From an alternative point of view, Rudenko et al. (2013) try to unify the concepts of value chain and WF in order to provide an integrated approach for the estimation of financial and freshwater resources of the cotton chain in Uzbekistan. As opposed to the rest WF studies in the sector, Rudenko et al. (2013) consider both microconomic and macroeconomic analyses of cotton production, processing and exports in Uzbekistan. According to the microeconomic results, the WF of a cotton t-shirt equals to $2,865 \mathrm{~m}^{3}$, while the respective value added is approximately 0.7 US dollars (USD) per item. From a macroeconomic perspective, the cotton exports amount to 1,234 million USD representing $22 \%$ of the total exports' volume, while the related WF equals to $20,286 \mathrm{~m}^{3}$ constituting $72 \%$ of the total WF of exports.

Except for the textile products, Zhang et al. (2014) quantify the industrial WF of three types of a typical zipper manufactured in China, namely one metal and two non-metal zippers, through using the WFA manual. The findings show that the metal zipper has the largest WF among the three product types. Painting, dyeing and primary processing constitute the top three water-consuming processes and contribute about $90 \%$ to the total WF. In particular, painting requires the largest volume of freshwater among all processes and accounts for more than $50 \%$ of the zippers' industrial WF. In addition, the grey water is the dominant WF component, contributing by $80 \%$ to the total water use.

In the cosmetics industry, Francke and Castro (2013) investigate the relationship between carbon and WF of a commercial 450 gr soap bar. The authors use primary data of a leading cosmetics company in Latin America to derive implications about balancing the trade-offs and environmental impact of carbon and WFs across supply chains of skin care and personal hygiene products. Using the WFA methodology, the green, blue, and grey waters equal to $1,581,1,587$ and $3,672 \mathrm{~L}$ per functional unit, respectively. Remarkably, $99 \%$ of the green WF is generated during the soap formation phase, whereas major volumes of blue and grey WFs occur during the use and disposal phases of the product. In the accompanying detergents industry, van Hoof et al. (2013) apply different LCA 
methods for assessing the WF of a hand dishwashing product manufactured in the UK and used in Germany and Spain. The authors select the cases of Spain and Germany due to the different water scarcity indexes that allow the investigation of the spatial differentiation in terms of water use. The majority of the indicators confirm that consumer use stage contributes by more than $90 \%$ to the total WF, given the direct water use during the dishwashing process, as well as the indirect water use due to electricity generation to heat the water.

\subsubsection{Water footprint of heavy industry products}

As regards pulp and paper industry, van Oel and Hoekstra (2012) and Manzardo et al. (2014) utilize the WFA methodology for the evaluation of water use. In particular, van Oel and Hoekstra (2012) quantify the WF of paper products manufactured in the Netherlands, taking into account both forestry and industrial stages of the production process. The study focuses on the assessment of the green and blue water, while the WF of paper is estimated between 2 and $13 \mathrm{~L}$ for an $A 4$ sheet. Similarly, Manzardo et al. (2014) calculate the WF of chemical pulp at an Italian pulp and paper factory. The outcomes of the assessment are used as inputs in a multi-objective linear model for identifying the optimal chemical pulp mix that minimizes both WFs and cost of procurement phase, which includes forest and pulp processing stages. According to the results, the optimal pulp mix contains various raw materials sourced from different Latin American countries. Furthermore, McDevitt et al. (2014) implement both the WFA method and a LCA-based technique to a tissue paper supply chain in New Zealand, spanning from forestry operations to waste disposal. The total volumetric WF of one $\mathrm{kg}$ of tissue paper equals to $1,284 \mathrm{~kg}$ of water, while the stress-weighted WF is $0.4 \mathrm{~kg}$ of water equivalent. The results indicate that water consumption and pollution across the tissue paper supply chain is high; however, the impact of water use is minimal due to significant water availability in New Zealand.

With reference to steel and metal industry, Gu et al. (2015) quantify both direct and indirect water use in an iron and steel factory in China, following a cumulative approach. The blue and grey 
WFs are calculated separately for better understanding the associated water risks. According to the obtained results, freshwater consumption and pollution equal to 5.5 and $146 \mathrm{~m}^{3}$ per $\mathrm{t}$ of steel, respectively, mainly due to the significant power requirements of the steelworks enterprise. Moreover, Buxmann et al. (2016) calculate the water scarcity impact of the annual global aluminium production through a plant-by-plant approach from cradle-to-gate. The authors utilize ISO 14046 as a roadmap to aggregate data of aluminium production sites at locations with different water scarcity indices. The findings show that the respective water scarcity footprint is $18 \mathrm{~m}^{3}$ of water equivalent per $t$ of primary aluminium.

Northey et al. (2014) conduct a LCA-based water accounting during mining and metal processing in Australia in order to calculate the consumptive and degradative water use of copper, gold and nickel products. According to the results, water consumption depends on the type of metal, the manufacturing process, as well as the local water scarcity, while water degradation is influenced by the local hydrology and the processing techniques. At the same time, Peña and Huijbregts (2014) calculate the blue WF during the production of two different types of high-purity copper in Chile based on their own developed LCA approach. The total direct and upstream blue WF for the sulphide ore production is $96 \mathrm{~m}^{3}$ per $\mathrm{t}$ of copper, while for the oxide ore production equals to $40 \mathrm{~m}^{3}$ per tof copper. In particular, the contribution of the upstream processes to the total blue WF is approximately $18.75 \%$ and $27.5 \%$ for the sulphide and oxide copper, respectively, mainly due to the water embodied in fuels used to produce electricity.

On the contrary, Haggard et al. (2015) and Ranchod et al. (2015) utilize the WFA methodology in order to assess the blue WF that is associated with the mining and refining operations of platinum in South Africa. According to Haggard et al. (2015), the total direct WF of platinum processing equals to 743 thousand $\mathrm{m}^{3}$ per $\mathrm{t}$ of platinum. Overall, the grey water rises up to $73 \%$ of the total WF, followed by the blue water, while there is no green water. Focusing on both direct and indirect water use, Ranchod et al. (2015) estimate the total blue WF at 2,229 thousand $\mathrm{m}^{3}$ per $\mathrm{t}$ of refined platinum. 
Specifically, the procedure of mineral processing is responsible for the majority of blue water consumption, contributing by $47.3 \%$. Although Ranchod et al. (2015) merely quantify consumptive water use, the results are significantly higher compared to those of Haggard et al. (2015) due the incorporation of the indirect WF related to mining and electricity production. However, the WF of platinum seems to be considerably greater in order of magnitude compared to other metals, such as copper (Peña and Huijbregts, 2014).

In the automotive industry, Berger et al. (2012) use LCA techniques, including ISO 14040 and ISO 14044 , in order to analyse freshwater consumption and pollution along the entire life cycles of three car models of the Volkswagen group (i.e. Polo 1.2 TDI, Golf 1.6 TDI and Passat 2.0 TDI). The authors emphasize on water scarcity of 43 regions, concerning operations that span from the production and procurement of raw materials to the end-of-life treatment. The results indicate that freshwater consumption for the Polo, Golf and Passat models equals to 52,63 and $83 \mathrm{~m}^{3}$, respectively. Remarkably, $90 \%$ of both consumptive and degradative WF is attributed to the production of iron, steel, metals and polymers, as well as the consumption of energy during manufacturing.

Concerning the energy sector, efforts focus on assessing the WF of both coal-fired (Pan et al., 2012) and natural gas-fired (Ali and Kumar, 2016) power generation systems. Specifically, Pan et al. (2012) provide an analysis of freshwater consumption in the coal supply chain in China, including coal mining and preparation, transportation, conversion and power generation. The findings reveal that the average water consumption is $2.85 \mathrm{~m}^{3}$ per megawatt hour (MWh). The authors further design possible scenarios of water use in China's coal supply chain. Scenario analyses indicate that coal-fired power generation will still account for the largest part of water use in the Chinese coal supply chain by 2030. In addition, Ali and Kumar (2016) provide a benchmark for the freshwater supplies required for natural gas-fired power generation. The authors investigate available data regarding water demand across 18 different pathways in the conversion process of natural gas to power. The findings highlight that the conversion efficiency has a major effect on the amount of 
freshwater consumed during the complete life cycles of the gas-fired power generation pathways. The numerical results indicate that annual water consumption ranges between 0.12 and $2.57 \mathrm{~m}^{3}$ per MWh, which is considered comparable with the coal-fired power results calculated by Pan et al. (2012). 
Table 1. Summary of the literature synthesis.

\begin{tabular}{|c|c|c|c|c|c|c|c|c|c|c|c|}
\hline \multirow[b]{2}{*}{ Sector } & \multirow[b]{2}{*}{ Reference } & \multirow[b]{2}{*}{ Methodology } & \multirow[b]{2}{*}{$\begin{array}{c}\text { Type of water } \\
\text { use }\end{array}$} & \multicolumn{7}{|c|}{ Supply Chain Echelon } & \multirow[b]{2}{*}{ Country } \\
\hline & & & & 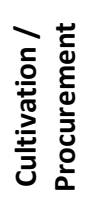 & 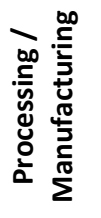 & 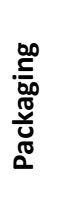 & 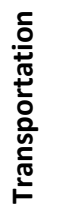 & 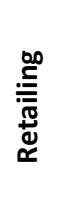 & 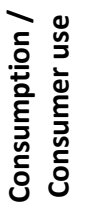 & 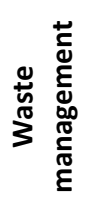 & \\
\hline \multirow{11}{*}{$\begin{array}{l}\overline{8} \\
\stackrel{0}{0} \\
\stackrel{0}{0} \\
\frac{000}{4}\end{array}$} & Aldaya and Hoekstra (2010) & WFA & $\begin{array}{l}\text { Consumptive, } \\
\text { degradative }\end{array}$ & $\bullet$ & $\bullet$ & & & & & & European countries \\
\hline & Almeida et al. (2014) & ISO 14040/44 & $\begin{array}{l}\text { Consumptive, } \\
\text { degradative }\end{array}$ & $\bullet$ & & & & & & & European countries \\
\hline & Antonelli and Ruini (2015) & WFA & $\begin{array}{c}\text { Consumptive, } \\
\text { degradative }\end{array}$ & $\bullet$ & $\bullet$ & $\bullet$ & $\bullet$ & & $\bullet$ & & Intercontinentality \\
\hline & Brodt et al. (2013) & ISO 14040 & Consumptive & $\bullet$ & - & $\bullet$ & $\bullet$ & & & & $\begin{array}{l}\text { North American } \\
\text { countries }\end{array}$ \\
\hline & de Figueirêdo et al. (2014) & LCA-based & Consumptive & - & $\bullet$ & $\bullet$ & $\bullet$ & & & • & $\begin{array}{l}\text { Latin American } \\
\text { countries }\end{array}$ \\
\hline & Ercin et al. (2012) & WFA & $\begin{array}{l}\text { Consumptive, } \\
\text { degradative }\end{array}$ & $\bullet$ & $\bullet$ & $\bullet$ & & & & & Intercontinentality \\
\hline & Ercin et al. (2011) & WFA & $\begin{array}{c}\text { Consumptive, } \\
\text { degradative }\end{array}$ & $\bullet$ & $\bullet$ & $\bullet$ & $\bullet$ & & & & Intercontinentality \\
\hline & *Hess et al. (2015) & $\begin{array}{l}\text { WFA, LCA-based, } \\
\text { other }\end{array}$ & Consumptive & $\bullet$ & & & & & & & European countries \\
\hline & *Hess et al. (2016) & LCA-based & Consumptive & • & - & $\bullet$ & $\bullet$ & & & & Intercontinentality \\
\hline & *Jefferies et al. (2012) & WFA, LCA-based & Consumptive & • & - & $\bullet$ & $\bullet$ & & $\bullet$ & • & Intercontinentality \\
\hline & Jeswani et al. (2015) & $\begin{array}{l}\text { WFA, LCA-based, } \\
\text { ISO 14040/44 }\end{array}$ & $\begin{array}{c}\text { Consumptive, } \\
\text { degradative }\end{array}$ & • & $\bullet$ & $\bullet$ & & & $\bullet$ & & Intercontinentality \\
\hline
\end{tabular}




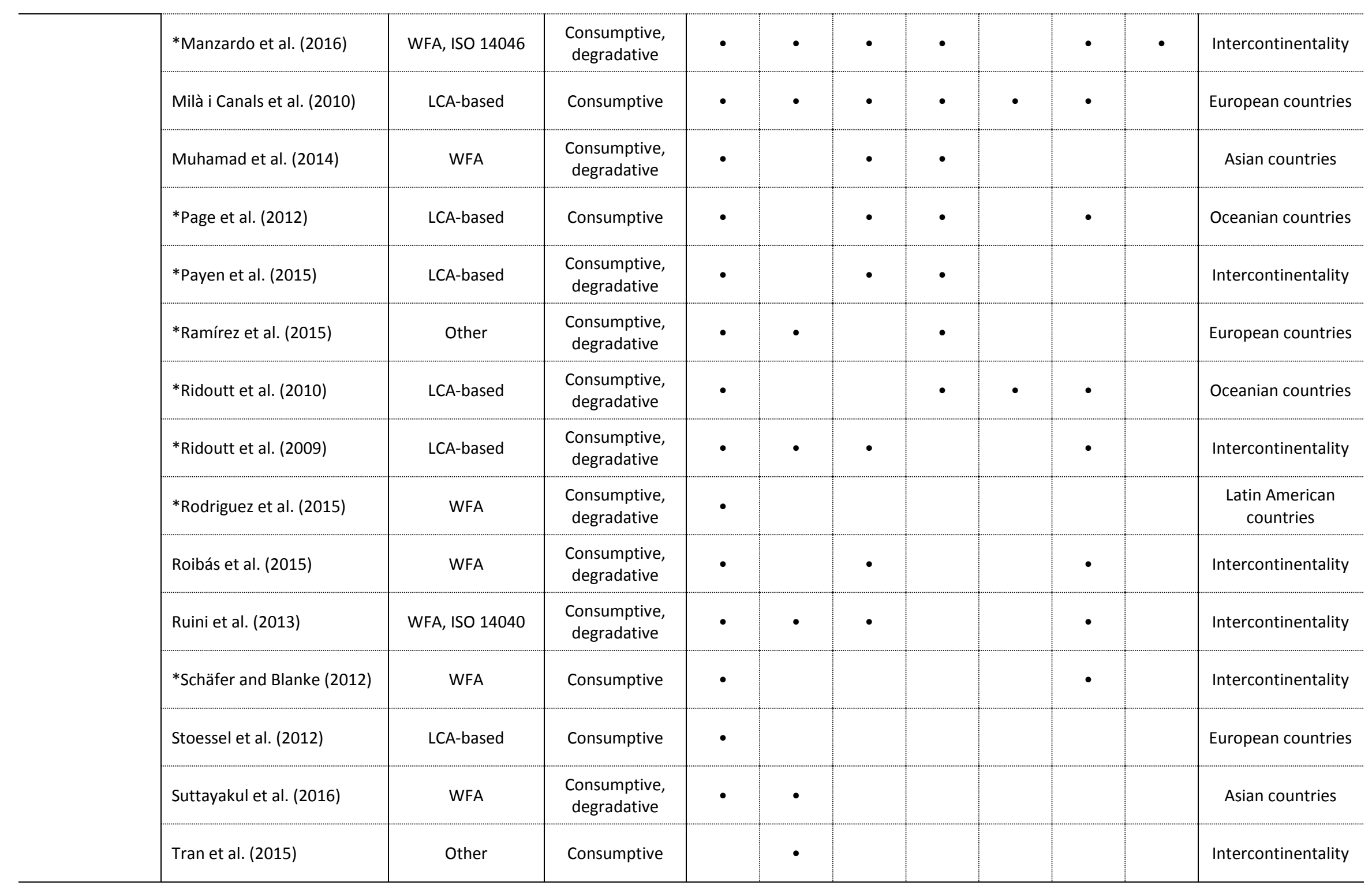




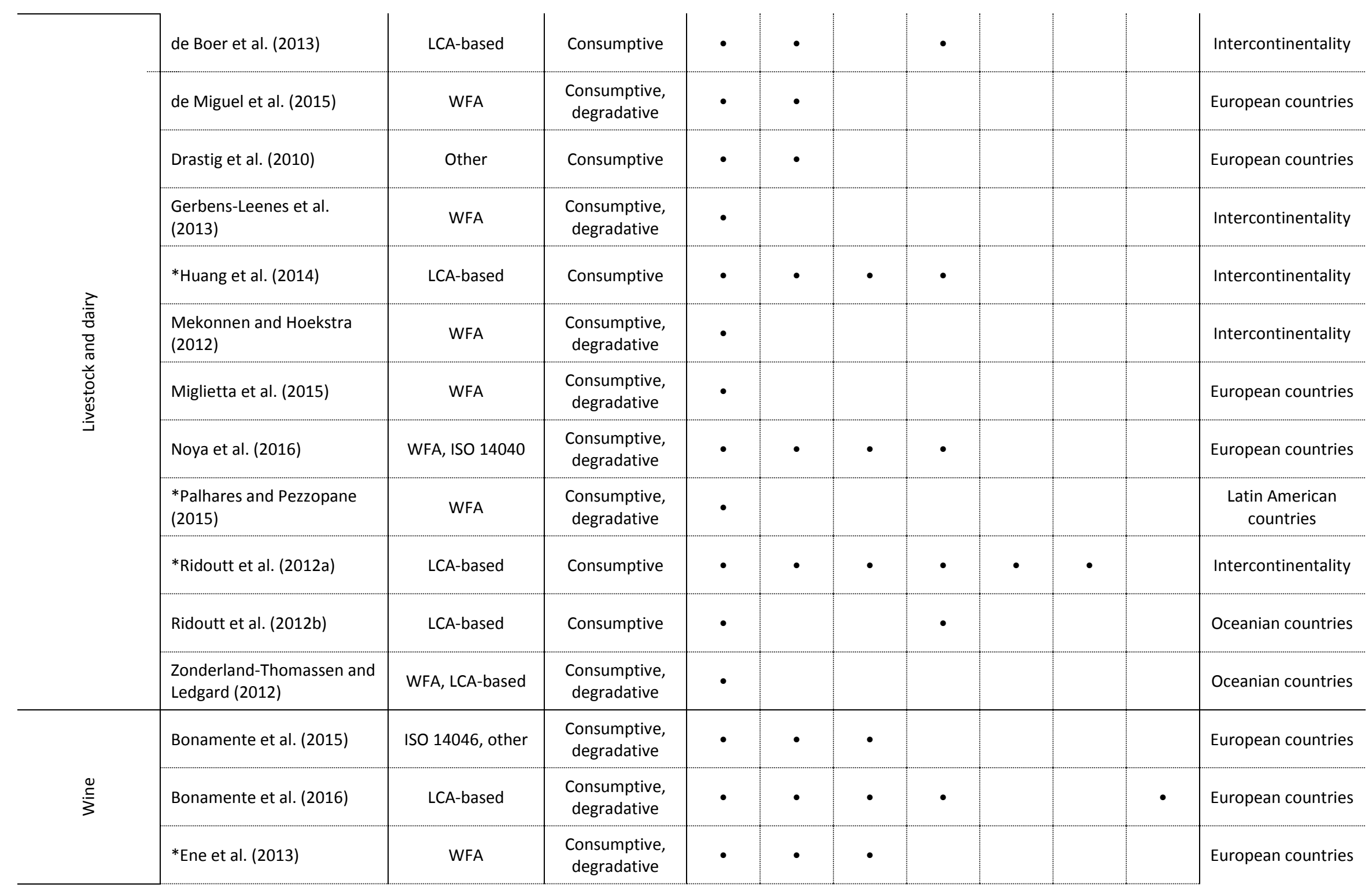




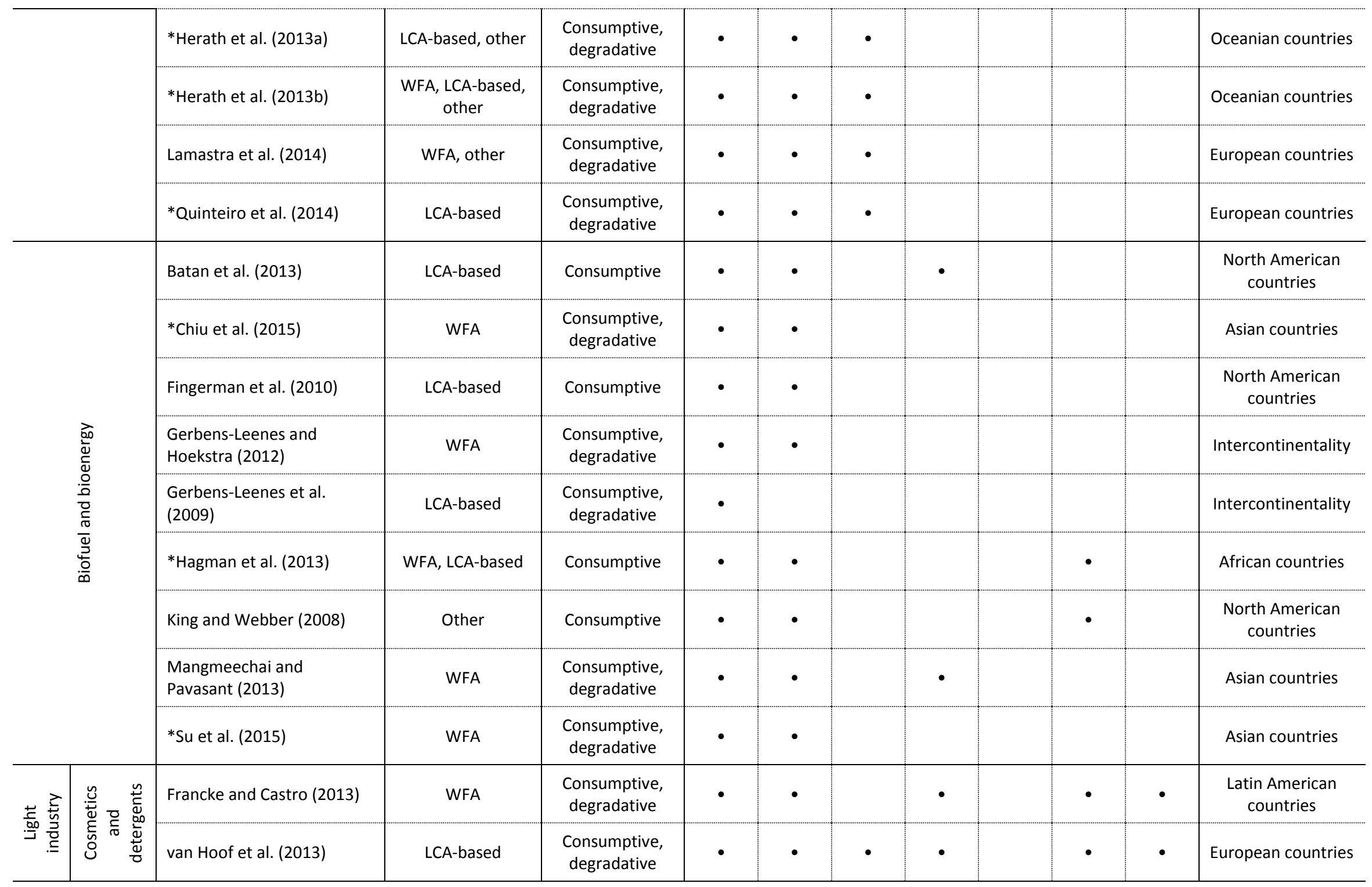




\begin{tabular}{|c|c|c|c|c|c|c|c|c|c|c|c|}
\hline & \multirow{6}{*}{ 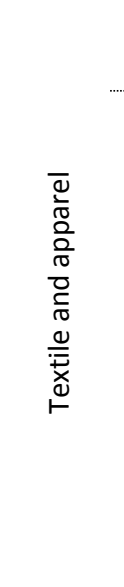 } & Chen et al. (2015) & Other & $\begin{array}{c}\text { Consumptive, } \\
\text { degradative }\end{array}$ & & • & & & & & Asian countries \\
\hline & & *Chico et al. (2013) & WFA & $\begin{array}{c}\text { Consumptive, } \\
\text { degradative }\end{array}$ & $\bullet$ & • & & & & & European countries \\
\hline & & *Joa et al. (2014) & Other & Consumptive & $\bullet$ & - & & & & & Intercontinentality \\
\hline & & Rudenko et al. (2013) & Other & $\begin{array}{c}\text { Consumptive, } \\
\text { degradative }\end{array}$ & $\cdot$ & - & & & & & Asian countries \\
\hline & & Wang et al. (2013) & Other & $\begin{array}{c}\text { Consumptive, } \\
\text { degradative }\end{array}$ & & $\cdot$ & & & & & Asian countries \\
\hline & & Zhang et al. (2014) & WFA & $\begin{array}{c}\text { Consumptive, } \\
\text { degradative }\end{array}$ & $\bullet$ & $\bullet$ & & & & & Asian countries \\
\hline \multirow{9}{*}{ 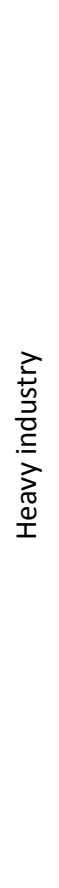 } & 菨 & Berger et al. (2012) & $\begin{array}{c}\text { LCA-based, ISO } \\
1440 / 44\end{array}$ & $\begin{array}{c}\text { Consumptive, } \\
\text { degradative }\end{array}$ & $\bullet$ & $\cdot$ & $\bullet$ & & $\bullet$ & - & Intercontinentality \\
\hline & \multirow{2}{*}{ 亭 } & Ali and Kumar (2016) & Other & Consumptive & $\cdot$ & $\bullet$ & $\bullet$ & & & & $\begin{array}{l}\text { North American } \\
\text { countries }\end{array}$ \\
\hline & & Pan et al. (2012) & Other & $\begin{array}{l}\text { Consumptive, } \\
\text { degradative }\end{array}$ & $\cdot$ & $\cdot$ & $\bullet$ & & & & Asian countries \\
\hline & \multirow{3}{*}{$\begin{array}{l}\bar{̀} \\
\frac{\overline{0}}{0} \\
\frac{0}{0} \\
\frac{0}{0} \\
\frac{0}{5} \\
\frac{0}{2}\end{array}$} & *Manzardo et al. (2014) & WFA & $\begin{array}{c}\text { Consumptive, } \\
\text { degradative }\end{array}$ & $\bullet$ & & & & & & Intercontinentality \\
\hline & & McDevitt et al. (2012) & WFA, LCA-based & $\begin{array}{c}\text { Consumptive, } \\
\text { degradative }\end{array}$ & $\cdot$ & $\cdot$ & $\bullet$ & $\bullet$ & $\bullet$ & - & Oceanian countries \\
\hline & & $\begin{array}{l}\text { van Oel and Hoekstra } \\
\text { (2012) }\end{array}$ & WFA & Consumptive & $\bullet$ & • & & & & & European countries \\
\hline & \multirow{3}{*}{ 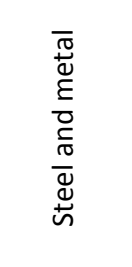 } & Buxmann et al. (2016) & ISO 14046 & Consumptive & $\bullet$ & • & • & & & & Intercontinentality \\
\hline & & *Gu et al. (2015) & Other & $\begin{array}{c}\text { Consumptive, } \\
\text { degradative }\end{array}$ & & $\bullet$ & & & & & Asian countries \\
\hline & & Haggard et al. (2015) & WFA & $\begin{array}{c}\text { Consumptive, } \\
\text { degradative }\end{array}$ & & • & & & & & African countries \\
\hline
\end{tabular}




\begin{tabular}{|c|c|c|c|c|c|c|}
\hline Northey et al. (2014) & LCA-based & $\begin{array}{l}\text { Consumptive, } \\
\text { degradative }\end{array}$ & $\cdot$ & - & & Oceanian countries \\
\hline Peña and Huijbregts (2014) & LCA-based & Consumptive & - & - & - & $\begin{array}{l}\text { Latin American } \\
\text { countries }\end{array}$ \\
\hline Ranchod et al. (2015) & WFA & Consumptive & - & - & & African countries \\
\hline
\end{tabular}

*Papers published in the Journal of Cleaner Production. 


\subsection{Results and discussion}

Figure 4 illustrates the allocation of the papers to the analysed production sectors, among which the agrifood sector embraces the majority of research efforts $(35 \%)$ concerning product WF assessment. Further taking into consideration the livestock, dairy and wine industries, WF accounting in the expanded food and beverage sector is cited by $61 \%$ of the publications. In addition, $12 \%$ of the case studies refers to water use in the biofuel and bioenergy sector, while the rest $27 \%$ quantifies WFs in both light and heavy industries. These results confirm that although agricultural processes undoubtedly constitute the main factor of freshwater exploitation worldwide (Rodriguez et al., 2015), several industrial processes of non-food products, such as textiles (Wang et al., 2013) or zippers (Zhang et al., 2014), are responsible for a considerable amount of supply chain WF. Especially concerning the heavy industry, the production of steel (Gu et al., 2015) and other metals, such as aluminium (Buxmann et al., 2016), copper (Peña and Huijbregts, 2014), gold (Northey et al., 2014) and platinum (Ranchod et al., 2015), entails the utilization of significant freshwater volumes.

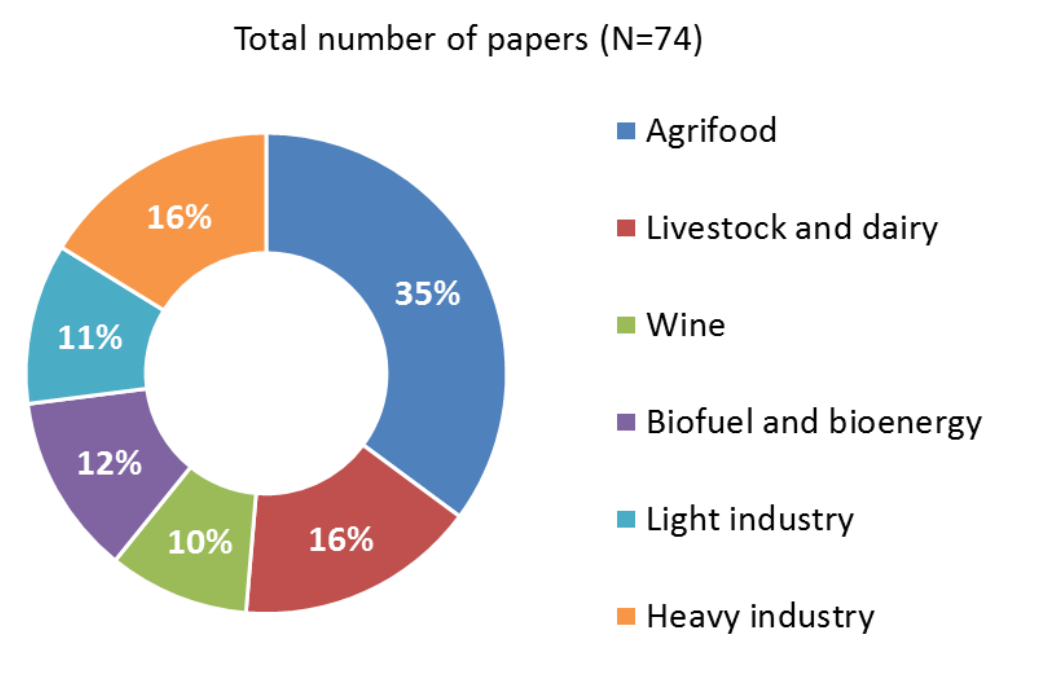

Figure 4. Distribution of publications per sector or industry.

As shown in Figure 5, the WFA method developed by Hoekstra et al. (2011) is used in 35\% of the reviewed publications, followed by various LCA-based techniques (26\%), such as that of Ridoutt and 
Pfister (2010). Moreover, 4\% of the articles utilize international standards as individual methodologies in order to calculate freshwater consumption and pollution. Specifically, Almeida et al. (2014) and Brodt et al. (2013) deploy the environmental ISO 14040 or ISO 14044 in the agrifood sector, while Buxmann et al. (2016) implement the water-related ISO 14046 in the mining sector. On the contrary, several papers apply alternative methods (15\%), including the hydrological waterbalance method developed by Deurer et al. (2011) and Herath et al. (2011), or the authors' own developed methodologies, such as those of Chen et al. (2015), Joa et al. (2014) and Wang et al. (2013) in the textile sector. At the same time, other $20 \%$ of the studies include multiple WF assessment methods utilized either in combination with one another or separately in order to compare the relevant results. Following a combinative approach, Herath et al. (2013a) implement various LCA and hydrological methodologies, while Hess et al. (2015) combine both the WFA method and a LCA-based technique together with their own developed methodology. Moreover, Lamastra et al. (2014) develop the WFA approach through integrating an improved method for quantifying the degradative water use in the wine sector. Based on the ISO guidelines, several authors utilize diverse methods for the WF calculations. Specifically, Noya et al. (2016) and Ruini et al. (2013) incorporate the WFA method into the ISO 14040, while Berger et al. (2012) and Jeswani et al. (2015) further apply a LCA-based approach. In addition, Bonamente et al. (2015) implement the Lamasta et al. (2014) method according to the water-related ISO 14046. In terms of comparison, Jefferies et al. (2012) and Zonderland-Thomassen and Ledgard (2012) in the food sector, Hagman et al. (2013) in the biofuel sector and McDevitt et al. (2012) in the industrial sector juxtapose the WFA technique with several LCA methods. Herath et al. (2013b) expand the WF evaluation, further taking into consideration the hydrological approach by Deurer et al. (2011). Finally, Manzardo et al. (2016) conduct WF assessment using both the WFA manual and the ISO 14046 in order to compare the obtained results. 


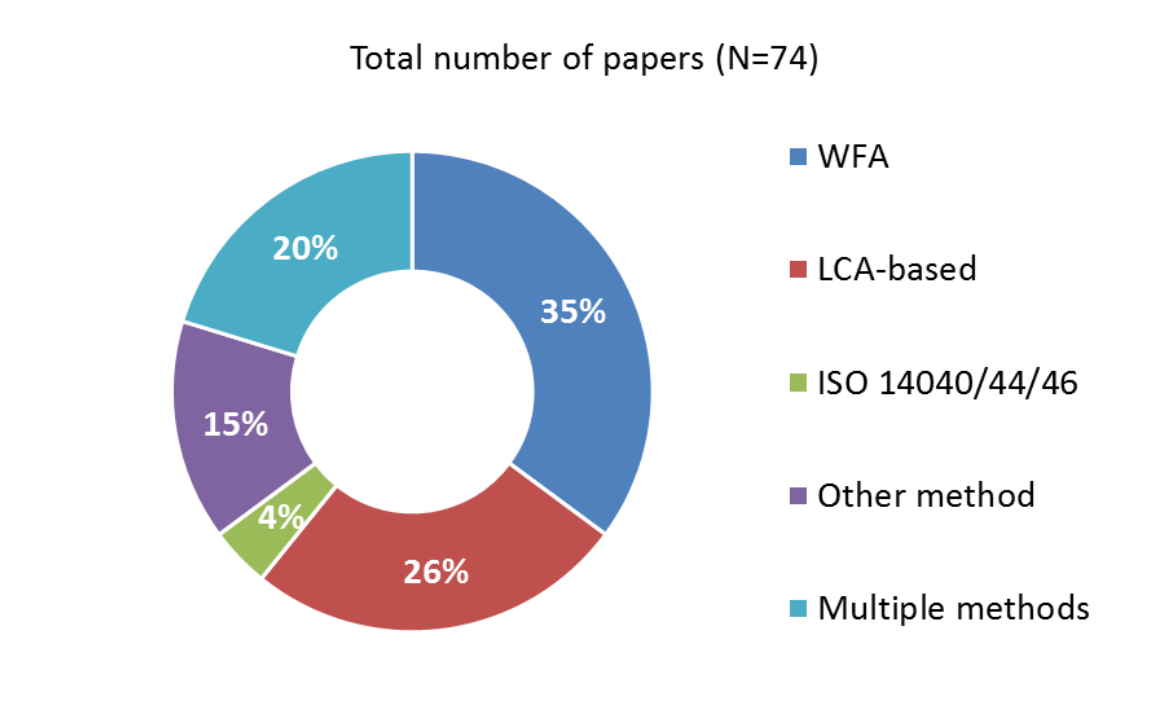

Figure 5. Distribution of publications per methodology.

The quantity of papers that assess water use at each supply chain echelon is depicted in Figure 6. In particular, procurement stage, or else cultivation stage for agricultural products, is cited by the vast majority of the collected papers $(93 \%)$ and is followed by the processing/manufacturing echelon (76\%). The results are consistent given that extraction of raw materials of either food (Ridoutt et al. 2009) or non-food (Manzardo et al., 2014) products, along with industrial processing, indicatively concerning automobile (Berger et al., 2012) or steel (Gu et al., 2015) production, consumes and pollutes significant amounts of freshwater resources in supply chains. Likewise, $36 \%$ and $39 \%$ of the publications calculate water use during packaging and transportation phases, respectively. More specifically, utilization of carton packages, which require significant amounts of freshwater for their production (Manzardo et al., 2016), and bottle washing (Ene et al., 2013) are considered as major WF contributors. At the same time, the use of biofuels in transportation, which are much more water consuming compared to fossil fuels (King and Weber, 2008), could significantly increase the total supply chain WF. In contrast, only a small fraction (5\%) of research efforts focuses on freshwater consumption or pollution in the retailing stage, further including the WF of food losses at this phase (Ridoutt et al., 2010) and the indirect WF mainly due to electricity consumption (McDevitt et al., 2012). Finally, the quantification of WF during consumption/consumer use and waste management echelons is conducted by $24 \%$ and $11 \%$ of the articles, respectively. In particular, 
freshwater is consumed during washing (Schäfer and Blanke, 2012) and cooking (Antonelli and Ruini, 2015) of agrifood products or during utilization of other consumer products, such as soap (Francke and Castro, 2013), dishwashing detergent (van Hoof et al., 2013) and tissue paper (McDevitt et al., 2012).

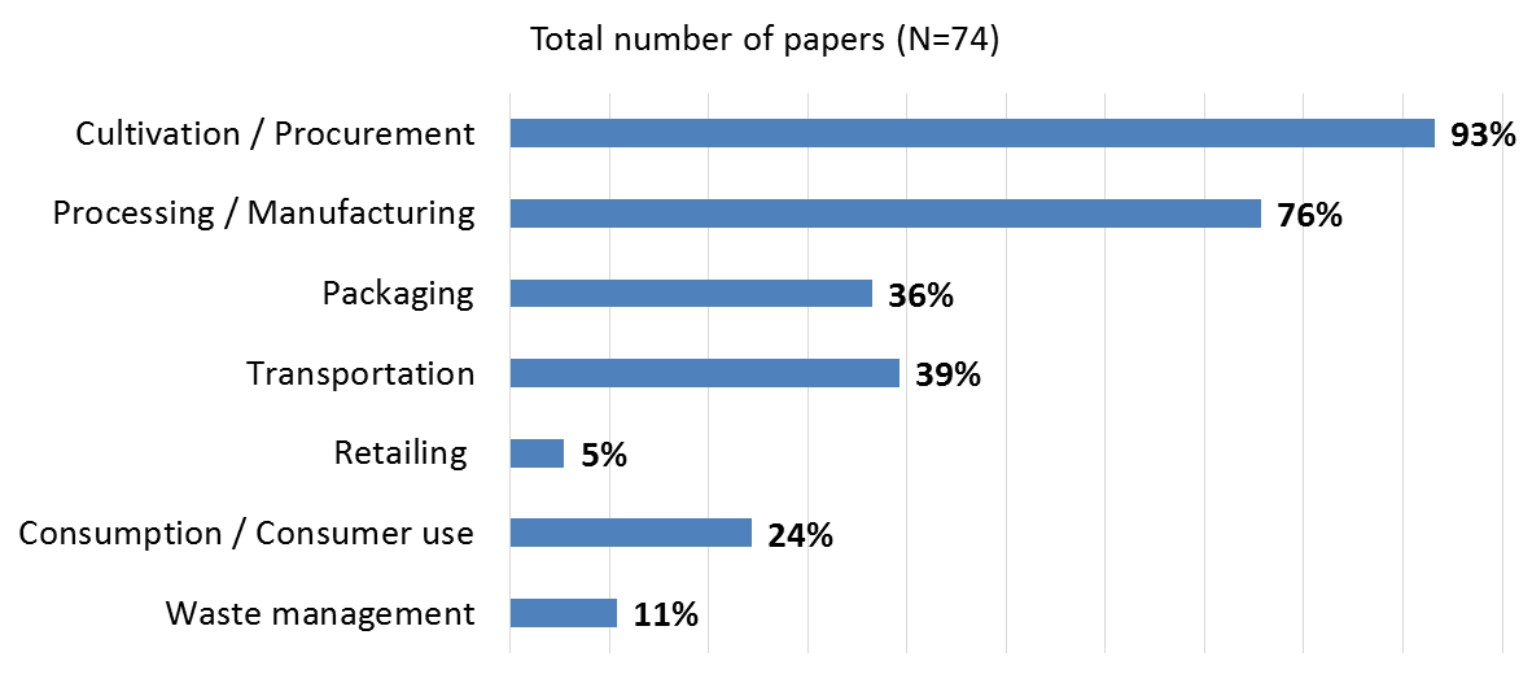

Figure 6. Percentage of publications focusing on each supply chain echelon.

Figure 7 illustrates the spatial allocation of the studies. The majority of the papers $(32 \%)$ refers to countries from multiple continents, followed by publications concerning European and Asian countries ( $24 \%$ and $15 \%$, respectively). Furthermore, $14 \%$ of the articles focus on WF assessment issues in North and Latin American countries, while $11 \%$ of the research is conducted in Oceanian countries. Case studies in African countries, namely those of Hagman et al. (2013) in the biofuel industry and Haggard et al. (2015) and Ranchod et al. (2015) in the metal industry, constitute only $4 \%$ of the reviewed publications. Notably, several papers include more than one countries given that the authors either compare the WF of similar products originated from different regions (e.g. Tran et al., 2015) or examine several supply chain operations performed in different countries (e.g. Jeswani et al., 2015). 


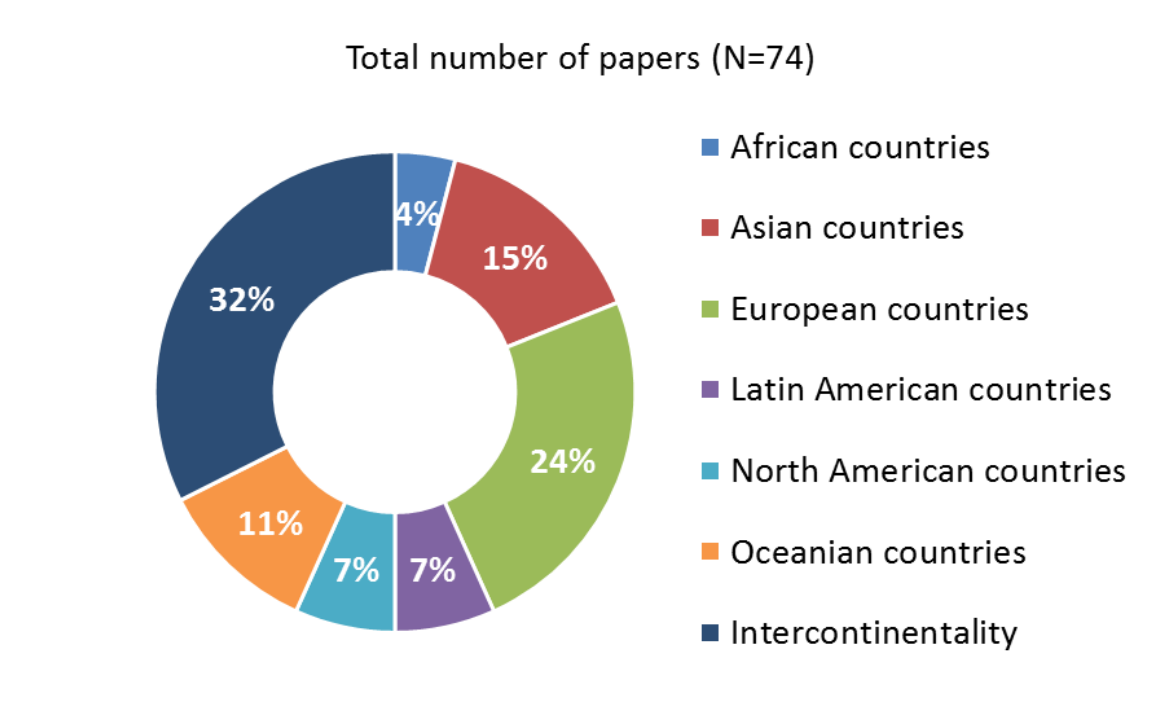

Figure 7. Distribution of publications per country.

Except for providing meaningful statistics, the scope of the synthesis is to document any gaps in the existing body of literature, as well as to identify opportunities for integrating water footprinting into supply chain management. First, we could highlight the rather limited yet rapidly increasing number of scientific contributions on product WF assessment. In fact, it is evident that published works in the field have increased significantly during the last five years, indicating the importance of evaluating freshwater consumption and pollution on a product scale. However, the comparative analysis of the studies is rather challenging due to significant differences concerning: (i) methodological approaches implemented, (ii) databases utilized, (iii) assumptions articulated, (iv) supply chain echelons examined, and (v) temporal or spatial characteristics considered. In particular, Danielsson et al. (2015) argue that it is infeasible to compare WF results derived from different methods, even though the calculations are performed using the same dataset. In fact, Bonamente et al. (2016) confirm this statement through providing different results compared to Bonamente et al. (2015), albeit utilizing the same input data. Nevertheless, even applying the same methodology, the inclusion of indirect water use (Ranchod et al., 2015), as well as the diverse climatic and geographical conditions in the case of agriculturally derived products (Brodt et al., 2013), considerably influences the assessment of WFs. This is even more obvious as only few research articles compare the obtained WF results with the findings provided by similar studies concerning agricultural products 
(Ridoutt et al., 2010), dairy products (Palhares and Pezzopane, 2015), wine (Quintero et al., 2014), biofuels (Su et al., 2015), as well as textile products (Chico et al., 2013).

At the same time, the synthesis reveals an unequal importance given to the types of water use. Specifically, $34 \%$ of the publications refer to freshwater consumption, while the rest $66 \%$ focuses on both freshwater consumption and pollution. Notably, none of the papers quantifies freshwater pollution as a standalone indicator, verifying Laspidou (2014) and Lovarelli et al. (2016) who argue that grey water is the least studied WF component, especially in the agricultural sector, due to difficulty in estimating the load of pollutants. With respect to additional environmental impacts, only a subset of publications (16\%) quantifies freshwater utilization in combination with greenhouse gas emissions and/or energy flows, allowing for a broad evaluation of sustainability across a product's life cycle. In the agrifood sector, Almeida et al. (2014) and Payen et al. (2015) calculate the energy, carbon and WFs of fresh tomatoes, whereas Brodt et al. (2013) and Page et al. (2012) focus on the total environmental impact of extended tomato supply chains. Excluding the energy footprint, Ramírez et al. (2015) quantify the carbon and WFs of dried tomato production. Similarly, Schäfer and Blanke (2012) study the carbon emissions and water use during pumpkin production and consumption. Tran et al. (2015) further evaluate the energy demand of cassava starch production, whereas Jeswani et al. (2015) address the issue of energy consumption in conjunction with freshwater utilization in a cereal supply chain. In addition, Stoessel et al. (2012) perform both carbon and WF assessment for a variety of fresh products. Noya et al. (2016) evaluate the greenhouse gas emissions and freshwater consumption of pork production, while Bonamente et al. (2016) calculate the same indicators across a wine supply chain. Finally, in the cosmetics industry, Francke and Castro (2013) assess the carbon and WFs across a soap supply chain. Particularly, the existence of case studies that focus on both energy and WF assessment supports the fact that energy and freshwater resources are interrelated (Mohtar and Daher, 2012); energy is essential for pumping during irrigation or wastewater treatment, while water is necessary for energy generation or cooling of industrial equipment. 
Above all, our analysis demonstrates a lack of research efforts on freshwater exploitation across the entire spectrum of supply chain operations. Although the vast majority of papers points out the major WF hotspots across the different production sectors, only a handful of publications provides a holistic approach addressing WF assessment from a product life cycle perspective. Actually, $28 \%$ of the publications address WF assessment in four or more echelons, whereas merely $8 \%$ of the papers analyses water use in six out of the seven identified supply chain echelons. In particular, McDevitt et al. (2012) exclude the packaging stage, while Jefferies et al. (2012), Manzardo et al. (2016) and van Hoof et al. (2013) do not consider the retailing echelon. Furthermore, the waste management phase is omitted by Milà i Canals et al. (2010) and Ridoutt et al. (2012a). As such, the necessity for further developing supply chain-oriented WF accounting is recognised. In addition to the evaluation of freshwater use in supply chains, the identification of WF mitigation practices for all major WF hotspots has emerged as a significant opportunity for further research (Quinteiro et al., 2014). More specifically, the management of freshwater supplies could further support corporate water stewardship through supplementing the WF assessment process. In this respect, the integration of the relevant decisions into a comprehensive methodological framework could assist in strategically allocating freshwater resources across supply chains in order to minimize corporate WFs and foster the sustainability of all stakeholders.

\section{Water footprint management for agrifood supply chains}

In this section, we review both academic and corporate literature on state-of-the-art WF mitigation policies with emphasis on corporations of the agrifood sector, which dominates global freshwater consumption and pollution. We then develop a novel holistic framework for water management in agrifood supply chains based on the natural hierarchy of the decision-making process.

\subsection{Sustainable practices for water footprint mitigation}


In the farming stage, the cultivation of crop varieties that have low requirements for irrigation is imperative (Hoekstra et al., 2011), particularly in water-scarce regions (Su et al., 2015), while the growing of rain-fed crops could further enhance freshwater sustainability in water-abundant regions (Antonelli and Ruini, 2015). Alternatively, as organic production implies less freshwater consumption and pollution, shifting to organic crops could further reduce both consumptive (Brodt et al., 2013) and degradative (Ercin et al., 2012) WFs. Moreover, the adoption of temporal irrigation schedules (Hoekstra et al., 2011) based on climatic (Hess et al., 2010) or field-specific (Rodriguez et al., 2015) conditions is critical for optimizing land productivity and water efficiency. The implementation of agricultural techniques, such as mulching for reducing water evaporation from the soil (Hoekstra et al., 2011), as well as drip (Manzardo et al., 2016) or deficit irrigation (Hess et al., 2010) for reducing irrigated water volumes, constitutes another prevalent practice for freshwater retention. At the same time, the optimal application of pesticides and fertilizers (Jeswani et al., 2015) could prevent leaching and runoff effects (Rodriguez et al., 2015), which are responsible for freshwater deprivation.

Given that agricultural activities are dominant contributors to the WF of agrifood supply chains, manufacturers should carefully select and collaborate with suppliers (Hoekstra et al., 2011) that: (i) deploy water-friendly farming practices (Coca-cola HBC, 2015), and (ii) collect (Unilever, 2013) and disclose (Ridoutt et al., 2009) relevant data. Likewise, sourcing from suppliers located in regions where local water scarcity is low (Huang et al., 2014), as well as changing the composition of the final food commodities aiming to contain water-friendly raw materials (Jeswani et al., 2015), could further reduce the total product WF. As regards internal industrial operations, the establishment of internal WF auditing (Ene et al., 2013) and control (Tsolakis et al., 2014) systems is necessitated in order to identify processes generating water losses and define methods for wastewater reduction (Barrington et al., 2013). It is also suggested that manufacturers should invest in water-efficient technologies that consume lower volumes of freshwater during processing (McKinsey and Company, 2009). In addition, the implementation of wastewater treatment techniques (Ene et al., 2013) that 
promote water reuse (McKinsey and Company, 2009) and recycling (Unilever, 2013) could further reduce freshwater utilization. As well, companies should minimize the use of toxic chemical substances during food processing in order to prevent water pollution (Ene et al., 2013).

A major share of the indirect water consumption is related to the food products' packaging. Practices such the reduction of unnecessary packaging or the utilization of alternative water-efficient packaging, for example the use of plastic instead of carton packages, are considered vital for the minimization of the total WF (Jeswani et al., 2015). Furthermore, investments in water-efficient washers (Ene et al., 2013) for some types of packages, such as bottles (Coca-Cola HBC, 2015), could reduce water use, while wastewater recycling programs during the cleansing of agricultural products (Coca-Cola HBC, 2015) or their packages (Dole, 2011) could assist in freshwater resources' preservation. With regard to transportation, climate change concerns highlight the use of biofuels as an alternative energy source. However, as biofuel crops compete with food crops in terms of freshwater resources, biofuels should be prudently used as transport fuels (Gerbens-Leenes et al., 2012). At the same time, poor preservation conditions of food during logistics operations result in increased food waste and indirect WF (Ridoutt et al., 2010), as the production of more food products for covering human nutritional needs leads to additional freshwater consumption and pollution.

In the retailing stage, the selection and cooperation with water-efficient manufacturers could promote the development of sustainable supply chains (Tesco, 2014). Concerning the reduction of direct WFs, retailing companies could implement WF auditing and reporting systems (Tesco, 2014), as well as invest in water-efficient cooling systems (Walmart, 2015). Furthermore, WF concerns necessitate the reduction of product waste due to limited food shelf life (Motoshita et al., 2013). Moreover, WF labelling in food products could be environmentally meaningful for both enterprises and consumers (Leach et al., 2016) in order to drive systemic changes towards green purchasing decisions and WF impact (Ridoutt et al., 2010). In addition, companies are highly encouraged to 
launch environmental campaigns in order to raise consumer awareness concerning the minimization of water consumption during the use phase of products (van Hoof et al., 2013).

\subsection{Hierarchical decision-making framework}

The management of freshwater resources across supply chain networks necessitates a wellstructured decision-making process. This is even more accentuated as sustainable water management could minimize the environmental impact of water risks within organizations (Christ, 2014), further fostering the corporate financial performance, especially in environmentally sensitive markets (Aivazidou et al., 2016). However, despite the fact that there is a plethora of WF mitigation policies as proposed by both scientific and business communities, there is a lack of integrated approaches for managing WFs along entire value chains (Aivazidou et al., 2015). Actually, only recently have Angelis-Dimakis et al. (2016) developed a methodological framework for improving the economic and environmental efficiency of agricultural or industrial water use systems through the selection, assessment and implementation of water-friendly technological interventions.

In this respect, based on the aforementioned proposed sustainable practices and our collaboration with leading European corporate and academic stakeholders in the context of the European Union FP7 REGPOT project "GREEN-AgriChains" (http://www.green-agrichains.eu/), we provide a first-effort hierarchical framework of all major strategic, tactical and operational decisions for corporate WF management in agrifood supply chains. This framework is by no means a rigid model including an exhaustive list of all relevant policies but rather acts as a collection of decisions that we have identified in our on-going research. With reference to the hierarchical levels, strategic decisions concern all supply chain stakeholders who are interested in developing policies or investing in practices for achieving crucial goals concerning WF reduction in a long-term horizon. WF management is related to medium-term decisions that convert strategies into actions at the tactical level, as well as short-term decisions that implement actions in the diverse supply chains echelons at 
the operational level. Based on the above distinction, the inclusive hierarchical decision-making scheme is depicted in Table 2. 
Table 2. Hierarchical decision-making framework.

\begin{tabular}{|c|c|c|c|c|c|c|c|c|}
\hline \multirow[b]{2}{*}{ Hierarchical level } & \multirow[b]{2}{*}{ Water footprint management decision } & \multicolumn{7}{|c|}{ Supply Chain Echelon } \\
\hline & & 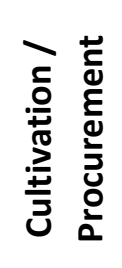 & 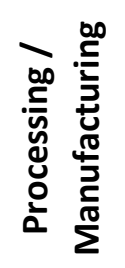 & 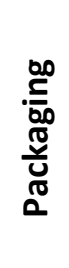 & $\begin{array}{l}\frac{5}{0} \\
\frac{0}{\pi} \\
\frac{t}{0} \\
\frac{0}{2} \\
\frac{1}{0} \\
\frac{10}{b}\end{array}$ & 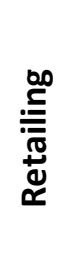 & 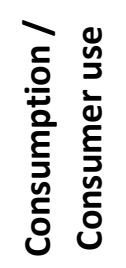 & 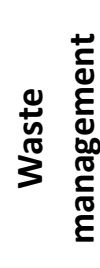 \\
\hline \multirow{6}{*}{ Strategic } & Cultivation of crops requiring less water & $\bullet$ & & & & & & \\
\hline & Alteration of conventional crops into organic crops & $\bullet$ & & & & & & \\
\hline & Selection and collaboration with water-friendly partners & & $\bullet$ & & & $\bullet$ & & \\
\hline & Establishment of water auditing and control systems & & $\bullet$ & & & $\bullet$ & & \\
\hline & Investment in water-efficient technologies & & $\bullet$ & $\bullet$ & & $\bullet$ & & $\bullet$ \\
\hline & Campaigns for raising consumer awareness & & & & & $\bullet$ & $\bullet$ & \\
\hline \multirow{5}{*}{ Tactical } & Use of precision techniques of irrigation and agriculture & $\bullet$ & & & & & & \\
\hline & Enhancement of water retention in the soil & $\bullet$ & & & & & & \\
\hline & Change in product composition & & $\bullet$ & & & & & \\
\hline & Reuse and recycling of wastewater & & $\bullet$ & $\bullet$ & & & & \\
\hline & Establishment of environmental labelling & & & & & $\bullet$ & & \\
\hline \multirow{5}{*}{ Operational } & Prudent use of pesticides and fertilizers & $\bullet$ & & & & & & \\
\hline & Prudent use of toxic chemical substances & & $\bullet$ & $\bullet$ & & & & $\bullet$ \\
\hline & Use of water-efficient packaging & & & $\bullet$ & & & & \\
\hline & Prudent use of biofuels in transport & & & & $\bullet$ & & & \\
\hline & Reduction of food waste & $\bullet$ & $\bullet$ & & $\bullet$ & $\bullet$ & & \\
\hline
\end{tabular}




\section{Conclusions}

Freshwater constitutes a vital resource in a plethora of agricultural and industrial activities (UN Water, 2009). As such, the overexploitation of available water supplies has motivated governmental authorities and business corporations to act towards the protection of freshwater resources through efficient WF assessment, management and monitoring (McKinsey and Company, 2009). Taking into consideration the supply chain perspective, this paper provides a critical literature synthesis on product WF assessment in multiple production sectors. Specifically, the findings of the synthesis indicate the following insights. First, the expanded agrifood sector, further including livestock, dairy and wine industries, is responsible for the majority of freshwater consumption and pollution worldwide, verifying Rodriguez et al. (2015) who argue that agricultural processes indisputably constitute the main contributor to freshwater exploitation. In addition, a lack of consensus in WF assessment tools is evident; as a result, the comparative analysis among the different studies is often impeded. However, the research field is mainly dominated by the WFA methodology and various LCA-based methods, including ISO standards. Nevertheless, attention should be paid to the variability of the performance of existing WF assessment approaches as this may enable the deliberate selection of a method that favours the calculation of water use (Danielsson et al., 2015). Concerning the types of water use, freshwater consumption prevails over freshwater degradation in terms of WF assessment, attesting the limited number of publications referring to water pollution (Laspidou, 2014). Notably, the research on product WF accounting is rapidly evolving. However, as several water accounting tools are relatively new, failing to address freshwater use in a holistic manner (Christ, 2014), there is a limited number of scientific publications that extend the analysis across entire supply chains from a cradle-to-grave perspective. At the same time, as global supply chain networks dictate the international dispersion of the related operations, product WF assessment often involves the implication of several countries with different climatic and 
geographical characteristics. In case local water stress is considered, this spreading further affects WF calculations (Jefferies et al., 2012).

As freshwater consumption and pollution are intertwined with several activities that act as WF hotspots, the implementation of WF mitigation policies across supply chains is necessitated (Quinteiro et al., 2014). In this context, this manuscript contributes towards incorporating efficient water management into supply chain management. Specifically, we provide a first-effort decisionmaking framework for holistic supply chain WF management in order to enhance corporate sustainability in terms of freshwater preservation. The framework is specifically honed for the agrifood sector, which has attracted the major share of the scientific publications on WF assessment according to our research. Given that an increasing number of companies are interested in adopting WF mitigation practices in the context of their corporate responsibility programs (CDP, 2015), the obtained managerial insights further highlight that WF management is an emerging research field among practitioners. To that end, the proposed framework aims at supporting agrifood corporations to establish their water stewardship policy in a systematic manner, through identifying and classifying a set of strategic, tactical and operational decisions for designing sustainable supply chains in terms of water use.

With respect to future scientific directions, we anticipate the progress of the research on supply chain-oriented WF assessment in order to add a holistic approach to the existing body of knowledge. More specifically, although agricultural products predominate in WF accounting studies (Lovarelli et al., 2016), additional focus should be placed on freshwater consumption and pollution across the life cycles of industrial products given that they entail complex supply chain networks. To this end, we suggest that the scientific community should elaborate on advancing the current WF assessment methodologies through developing an integrated approach that could systematically incorporate the quantification of consumptive and degradative water use in all industrial and supply chain operations. Furthermore, as several publications focus on the assessment of multiple environmental 
indicators (Payen et al., 2015), an extensive analysis on product-specific energy, carbon and WFs in different economic sectors is recommended. This research could foster the development of a novel methodology for combining and evaluating footprints across a product's life cycle in order to ensure overall environmental prosperity (Čuček et al., 2015). However, as, for example, freshwater scarcity is a markedly regional issue in contrast to greenhouse gas emissions that contribute to global climate change (Ridoutt et al., 2009), the analysis should focus on the trade-offs among the diverse indicators always from a supply chain perspective. Finally, building on state-of-the-art methodological frameworks for improving eco-efficiency (Angelis-Dimakis et al., 2016), we envision the development of a comprehensive approach for assessing sustainable policy interventions and managing energy consumption, carbon emissions and freshwater utilization in order to support holistic decision-making in globalized supply chains.

\section{Acknowledgements}

One of the authors (E.A.) would like to express her sincere thanks to the Public Benefit Foundation Alexander S. Onassis for financially supporting this research work as a part of her doctoral studies. In addition, this paper has been conducted in the context of the GREEN-AgriChains project that has received funding by the European Community's $7^{\text {th }}$ Framework Programme (FP7REGPOT-2012-2013-1) under grant agreement No 316167.

\section{References}

Aivazidou, E., Tsolakis, N., Vlachos, D., lakovou, E., 2015. Water Footprint Management Policies for Agrifood Supply Chains: A Critical Taxonomy and a System Dynamics Modelling Approach. Chemical Engineering Transactions 43, 115-120.

Aivazidou, E., Tsolakis, N., Vlachos, D., lakovou, E., 2016. Water Footprint Mitigation Strategies for Agrifood Products: The Application of System Dynamics in Green Marketing. In: A. Kavoura, D.P. 
Sakas, P. Tomaras, eds. 2016. Springer Proceedings in Business and Economics: Strategic Innovative Marketing. Gham: Springer International Publishing. Ch.35.

Aldaya, M.M., Hoekstra, A.Y., 2010. The water needed for Italians to eat pasta and pizza. Agricultural Systems 103, 351-360.

Ali, B., Kumar, A., 2016. Development of life cycle water footprints for gas-fired power generation technologies. Energy Conversion and Management 110, 386-396.

Allan, J.A., 1998. Virtual Water: A Strategic Resource - Global Solutions to Regional Deficits. Groundwater 36 (4), 545-546.

Almeida, J., Achten, W.M.J., Verbist, B., Heuts, R.F., Schrevens, E., Muys, B., 2014. Carbon and Water Footprints and Energy Use of Greenhouse Tomato Production in Northern Italy. Journal of Industrial Ecology 18(6), 898-908.

Angelis-Dimakis, A., Arampatzis, G., Assimacopoulos, D., 2016. Systemic eco-efficiency assessment of meso-level water use systems. Journal of Cleaner Production, In Press.

Antonelli, M., Ruini, L.-F., 2015. Business Engagement with Sustainable Water Resource Management through Water Footprint Accounting: The Case of the Barilla Company. Sustainability 7, 6742-6758.

Barrington, D.-J., Prior, A., Ho, G., 2013. The role of water auditing in achieving water conservation in the process industry. Journal of Cleaner Production 52, 356-361.

Batan, L., Quinn, J.C., brandley, T.H., 2013. Analysis of water footprint of a photobioreactor microalgae biofuel production system from blue, green and lifecycle perspectives. Algal Research 2, 196-203. 
Berger, M., Warsen, J., Krinke, S., Bach, V., Finkbeiner, M., 2012. Water Footprint of European Cars: Potential Impacts of Water Consumption along Automobile Life Cycles. Environmental Science and Technology 46, 4091-4099.

Bonamente, E., Scrucca, F., Asdrubali, F., Cotana, F., Presciutti, A., 2015. The Water Footprint of the Wine Industry: Implementation of an Assessment Methodology and Application to a Case Study. Sustainability 7, 12190-12207.

Bonamente, E., Scrucca, F., Rinaldi, S., Merico, M.-C., Asdrubali, D., Lamastra, L., 2016. Environmental impact of an Italian wine bottle: Carbon and water footprint assessment. Science of the Total Environment 560-561, 274-283.

Brodt, S., Kramer, J.K., Kendall, A., Feenstra, G., 2013. Comparing environmental impacts of regional and national-scale food supply chains: A case study of processed tomatoes. Food policy 42, 106114.

Buxmann, K., Koehler, A., Thylmann, D., 2016. Water scarcity footprint of primary aluminium. International Journal of Life Cycle Assessment, In Press.

Cellura, M., Ardente, F., Longo, S., 2012. From the LCA of food products to the environmental assessment of protected crops districts: A case-study in the south of Italy. Journal of Environmental Management 93, 194-208.

Chen, L., Ding, X., Wu, X., 2015. Water Management Tool of Industrial Products: A case study of screen printing fabric and digital printing fabric. Ecological Indicators 58, 86-94.

Chico, D., Aldaya, M.M., Garrido, A., 2013. A water footprint assessment of a pair of jeans: the influence of agricultural policies on the sustainability of consumer products. Journal of Cleaner Production 57, 238-248. 
Chiu, C.-C., Shiang, W.-J., Lin, C.-J., Wang, C.-H., Chang, D.-M., 2015. Water footprint analysis of second-generation bioethanol in Taiwan. Journal of Cleaner Production 101, 271-277.

Christ, K.L., 2014. Water management accounting and the wine supply chain: Empirical evidence from Australia. The British Accounting Review 46, 379-396.

CDP, 2015. Accelerating action - CDP Global Water Report 2015. [pdf] London: Carbon Disclosure Project. Available at: https://www.cdp.net/CDPResults/CDP-Global-Water-Report-2015.pdf [Accessed 04 February 2016].

Coca-Cola HBC, 2015. It's good to share Building trust, inspiring a better future - Water and Water Stewardship. [pdf] Zug: Coca-Cola Hellenic Bottling Company. Available at: http://www.cocacolahellenic.com/ /media/Files/C/CCHBC/documents/Issue Brief Water email web.pdf [Accessed 15 March 2016].

Čuček, L., Klemeš, J.J., Varbanov, P.S., Kravanja, Z., 2015. Significance of environmental footprints for evaluating sustainability and security of development. Clean Technologies and Environmental Policy 17, 2125-2141.

Danielsson, L., Skenhall, S., Rydberg, T., Nilsson, Å., 2015. EcoWater report - Comparing water footprint methods: The importance of a life cycle approach in assessing water footprint. [pdf] Stockholm: IVL Swedish Environmental Research Institute. Available at: http://www.ivl.se/download/18.343dc99d14e8bb0f58b7739/1445517875373/C98.pdf [Accessed 27 May 2016].

de Boer, I.J.M., Hoving, I.E., Vellinga, T.V., van de Ven, G.W.J., Leffelaar, P.A., Gerber P.J., 2013. Assessing environmental impacts associated with freshwater consumption along the life cycle of animal products: the case of Dutch milk production in Noord-Brabant. International Journal of Life Cycle Assessment 18, 193-203. 
de Figueirêdo, M.-C.-B., de Boer, I.J.M., Kroeze, C., da Silva Barros, V., de Sousa, J.-A., de Aragão, F.A.-S., Gondim, R.-S., Potting, J., 2014. Reducing the impact of irrigated crops on freshwater availability: the case of Brazilian yellow melons. International Journal of Life Cycle Assessment 19, 437-448.

de Miguel, A., Hoekstra, A.Y., García-Calvo, E., 2015. Sustainability of the water footprint of the Spanish pork industry. Ecological Indicators 57, 465-474.

Deurer, M., Green, S.R., Clothier, B.E., Mowat, A., 2011. Can product water footprints indicate the hydrological impact of primary production? A case study of New Zealand kiwifruit. Journal of Hydrology 408, 246-256.

Dole, 2011. Water Management - Water Recycling Programs for Banana Packing. [online] Available at: http://dolecrs.com/sustainability/water-management/water-recycling-programs-for-bananapacking/ [Accessed 15 March 2016].

Drastig, K., Prochnow, A., Kraatz, A., Klauss, H., Plöchl, M., 2010. Water footprint analysis for the assessment of milk production in Brandenburg (Germany). Advances in Geosciences 27, 65-70.

E4WATER, 2016. Economically and ecologically efficient water management in the European chemical industry - Solutions for Practice. [pdf] Frankfurt: DECHEMA. Available at: http://www.e4water.eu/ media/E4Water final brochure.pdf [Accessed 18 May 2016].

EcoWater, 2014. Deliverable 6.14: EcoWater Science-Policy Briefs. [online] Available at: http://environ.chemeng.ntua.gr/ecoWater/UserFiles/files/6 14\%20EcoWater\%20SciencePolicy\%20Briefs.pdf [Accessed 18 May 2016].

Ene, S.-A., Teodosiu, C., Robu, B., Volf, I., 2013. Water footprint assessment in the winemaking industry: a case study for a Romanian medium size production plant. Journal of Cleaner Production 43, 122-135. 
Ercin, A.E., Aldaya, M.M., Hoekstra A.Y., 2011. Corporate Water Footprint Accounting and Impact Assessment: The Case of the Water Footprint of a Sugar-Containing Carbonated Beverage. Water Resources Management 25, 721-741.

Ercin, A.E., Aldaya, M.M., Hoekstra A.Y., 2012. The water footprint of soy milk and soy burger and equivalent animal products. Ecological Indicators 18, 392-402.

Ercin, A.E., Hoekstra, A.Y., 2014. Water footprint scenarios for 2050: a global analysis. Environment International 64, 71-82.

European Union, 2000. Directive 2000/60/EC of the European Parliament and of the Council of 23 October 2000 establishing a framework for the Community action in the field of water policy. Brussels: European Union.

Fingerman, K.R., Torn, M.S., O'Hare, M.H., Kammen, D.M., 2010. Accounting for the water impacts of ethanol production. Environmental Research Letters 5, 1-7.

Francke, I.C.M., Castro, J.F.W., 2013. Carbon and water footprint analysis of a soap bar produced in Brazil by Natura Cosmetics. Water Resources and Industry 1-2, 37-48.

Gerbens-Leenes, W., Hoekstra A.Y., 2012. The water footprint of sweeteners and bio-ethanol. Environment International 40, 202-211.

Gerbens-Leenes, P.W., Hoekstra A.Y., van der Meer, Th., 2009. The water footprint of energy from biomass: A quantitative assessment and consequences of an increasing share of bio-energy in energy supply. Ecological Economics 68, 1052-1060.

Gerbens-Leenes, P.W., Mekonnen, M.M., Hoekstra, A.Y., 2013. The water footprint of poultry, pork and beef: A comparative study in different countries and production systems. Water Resources and Industry 1-2, 25-36. 
Gerbens-Leenes P.W., van Lienden A.R., Hoekstra A.Y., van der Meer T.H., 2012. Biofuel scenarios in a water perspective: The global blue and green water footprint of road transport in 2030. Global Environmental Change 22(3), 764-775.

Gu, Y., Xu, J., Keller, A.A., Yuan, D., Li, Y., Zhang, B., Weng, Q., Zhang, X., Deng, P., Wang, H., Li, F., 2015. Calculation of water footprint of the iron and steel industry: a case study in Eastern China. Journal of Cleaner Production 92, 274-281.

Haggard, E., Sheridan, C.M., Harding, K.G., 2015. Quantification of water usage at a South African platinum processing plant. Water SA 41(2), 279-286.

Hagman, J., Nerentorp, M., Arvidsson, R., Molander, S., 2013. Do biofuels require more water than do fossil fuels? Life cycle-based assessment of jatropha oil production in rural Mozambique. Journal of Cleaner Production 53, 176-185.

Herath, I., Deurer, M., Horne, D., Singh, R., Clothier, B., 2011. The water footprint of hydroelectricity: a methodological comparison from a case study in New Zealand. Journal of Cleaner Production 19(14), 1582-1589.

Herath, I., Green, S., Horne, D., Singh, R., McLaren, S., Clothier, B., 2013b. Water footprinting of agricultural products: evaluation of different protocols using a case study of New Zealand wine. Journal of Cleaner Production 44, 159-167.

Herath, I., Green, S., Singh, R., Horne, D., van den Zijpp, S., Clothier, B., 2013a. Water footprinting of agricultural products: a hydrological assessment for the water footprint of New Zealand's wines. Journal of Cleaner Production 41, 232-243.

Hess, T., Aldaya, M., Fawell, J., Franceschini, H., Ober, E., Schaub, R., Schulze-Aurich, J., Understanding the impact of crop and food production on the water environment - using sugar as a model. Journal of the Science of Food and Agriculture 94, 2-8. 
Hess, T., Chatterton, J., Daccache, A., Williams, A., 2016. The impact of changing food choices on the blue water scarcity footprint and greenhouse gas emissions of the British diet: the example of potato, pasta and rice. Journal of Cleaner Production 112, 4558-4568.

Hess, T.M., Lenard, A.T., Daccache, A., 2015. Comparing local and global water scarcity information in determining the water scarcity footprint of potato cultivation in Great Britain. Journal of Cleaner Production 87, 666-674.

Hoekstra, A.Y., 2008. Water Neutral: Reducing and Offsetting the Impacts of Water Footprints Value of Water Research Report Series No. 28. Delft: UNESCO-IHE.

Hoekstra, A.Y., 2011. Europe's Water Footprint - Striding Towards Sustainability. Water and Wastewater International 26 (2), 24-26.

Hoekstra, A.Y., Chapagain, A.K., Aldaya, M.M. and Mekonnen, M.M., 2011. The Water Footprint Assessment Manual: Setting the Global Standard. London: Earthscan.

Hoekstra, A.Y., Hung, P.Q., 2002. Virtual Water Trade: A Quantification of Virtual Water Flows between Nations in Relation to International Crop Trade - Value of Water Research Report Series No. 11. Delft: UNESCO-IHE.

Huang, J., Xu, C.-C., Ridoutt, B.G., Liu, J.-J., Zhang H.-L., Chen, F., Li, Y., 2014. Water availability footprint of milk and milk products from large-scale dairy production systems in Northeast China. Journal of Cleaner Production 79, 91-97.

Huerta, A.-R., Güereca, L.-P., Lozano, M.-S.-R., 2016. Environmental impact of beef production in Mexico through life cycle assessment. Resources, Conservation and Recycling 109, 44-53.

lakovou, E., Karagiannidis, D., Vlachos, A., Toka, A., Malamakis, A., 2010. Waste biomass-to-energy supply chain management: A critical synthesis. Waste Management 30, 1860-1870. 
ISO, 2006. ISO standards for life cycle assessment to promote sustainable development. [online] Available at: http://www.iso.org/iso/home/news index/news archive/news.htm?refid=Ref1019 [Accessed 04 February 2016].

ISO, 2014. ISO 14046:2014 - Environmental management - Water footprint - Principles, requirements and guidelines. Geneva: International Organization for Standardization.

Jefferies, D., Muñoz, I., Hodges, J., King, V.J., Aldaya, M., Ercin, A.-E., Milà i Canals, L., Hoekstra, A.Y., 2012. Water Footprint and Life Cycle Assessment as approaches to assess potential impacts of products on water consumption. Key learning points from pilot studies on tea and margarine. Journal of Cleaner Production 33, 155-166.

Jeswani, H.-K., Burkinshaw, R., Azapagic, A., 2015. Environmental sustainability issues in the foodenergy-water nexus: Breakfast cereals and snacks. Sustainable Production and Consumption 2, 17-28.

Joa, B., Hottenroth, H., Jungmichel, N., Schmidt, M., 2014. Introduction of a feasible performance indicator for corporate water accounting - a case study on the cotton textile chain. Journal of Cleaner Production 82, 143-153.

King, C.W., Weber, M.E., 2008. Water Intensity of Transportation. Environmental Science and Technology 42, 7866-7872.

Kounina, A., Margni, M., Bayart, J.-B., Boulay, A.M., Berger, M., Bulle, C., Frischknecht, R., Koehler, A., Milà i Canals, L., Motoshita, M., Núñez, M., Peters, G., Pfister, S., Ridoutt, B., Van Zelm, R., Francesca, F., Humbert, S., 2013. Review of methods addressing freshwater use in life cycle inventory and impact assessment. International Journal of Life Cycle Assessment 18, 707-721.

Lamastra, L., Suciu, N.-A., Novelli, E., Trevisan, M., 2014. A new approach to assessing the water footprint of wine: An Italian case study. Science of the Total Environment 490, 748-756. 
Laspidou, C.S., 2014. Grey Water Footprint of Crops and Crop-Derived Products: Analysis of Calculation Method. Fresenius Environmental Bulletin 23(11a), 2899-2903.

Leach, A.M., Emery, K.A., Gephart, J., Davis, K.F., Erisman, J.W., Leip, A., Pace, M.L., d'Odorico, P., Carr, J., Cattell Noll, L., Castner, E., Galloway, J.N., 2016. Environmental impact food labels combining carbon, nitrogen, and water footprints. Food Policy 61, 213-223.

Levidow, L., Lindgaard-Jørgensen, P., Nilsson, Å., Skenhall, S.-A., Assimacopoulos, D., 2016. Process eco-innovation: assessing meso-level eco-efficiency in industrial water-service systems. Journal of Cleaner Production 110, 54-65.

Levy, Y., Ellis, T.J., 2006. A Systems Approach to Conduct an Effective Literature Review in Support of Information Systems Research. Informing Science Journal 9, 181-212.

Lovarelli, D., Bacenetti, J., Fiala, M., 2016. Water Footprint of crop productions: A review. Science of the Total Environment 548-549, 236-251.

Mangmeechai, A., Pavasant, P., 2013. Water Footprints of Cassava- and Molasses-Based Ethanol Production in Thailand. Natural Resources Research 22(4), 273-282.

Manzardo, A., Mazzi, A., Loss, A., Butler, M., Williamson, A., Scipioni, A., 2016. Lessons learned from the application of different water footprint approaches to compare different food packaging alternatives. Journal of Cleaner Production 112, 4657-4666.

Manzardo, A., Ren, J, Piantella, A., Mazzi, A., Fedele, A., Scipioni, A., 2014. Integration of water footprint accounting and costs for optimal chemical pulp supply mix in paper industry. Journal of Cleaner Production 72, 167-173.

McDevitt, J.E., Love, S.R., Seadon, J.K., Allison, R.W., 2012. An evaluation of alternative water footprint methodologies using an indicative tissue paper supply chain. Appita Journal 65(2), 159164. 
McKinsey and Company, 2009. The global corporate footprint - Risks, opportunities and management options. [pdf] New York City: McKinsey and Company. Available at: http://www.mckinsey.com/ /media/mckinsey/dotcom/client service/Sustainability/PDFs/Report Large Water Users.ashx [Accessed 04 February 2016].

Mekonnen, M.M., Hoekstra, A.Y., 2012. A Global Assessment of the Water Footprint of Farm Animal Products. Ecosystems 15, 401-415.

Miglietta, P.-P., de Leo, F., Ruberti, M., assari, F., 2015. Mealworms for Food: A Water Footprint Perspective. Water 7, 6190-6203.

Milà i Canals, L., Chapagain, A., Orr, S., Chenoweth, J., Anton, A., Clift, R., 2010. Assessing freshwater use impacts in LCA, part 2: case study of broccoli production in the UK and Spain. International Journal of Life Cycle Assessment 15, 598-607.

Mirabella, N., Castellani, V., Sala, S., 2014. LCA for assessing environmental benefit of eco-design strategies and forest wood short supply chain: a furniture case study. International Journal of Life Cycle Assessment 19, 1536-1550.

Mohtar, R.H., Daher, B., 2012. Water, Energy, and Food: The Ultimate Nexus. In: D.R. Heldman, C.I. Moraru, eds. 2012. Encyclopedia of Agricultural, Food, and Biological Engineering, Second Edition. Abingdon: Taylor and Francis.

Mongeon, P., Paul-Hus, A., 2016. The journal coverage of Web of Science and Scopus: a comparative analysis. Scientometrics 106, 213-228.

Motoshita, M., Tahara, K., Itsubo, N., Inaba, A., 2013. The effectiveness of water footprint reduction and trade-off among environmental categories in the introduction of innovative packaging system for ready meal. In: The Swedish Life Cycle Center, $6^{\text {th }}$ International Conference on Life 
Cycle Management. Gothenburg, Sweden, 25-28 August 2013. Gothenburg: Chalmers University of Technology.

Muhamad, H., Subramaniam, V., Hashim, Z., Khairuddin, N.-S.-K., May, C.-Y., 2014. Water Footprint: Part 1 - Production of Oil Palm Seedlings in Peninsular Malaysia. Journal of Oil Palm Research 26(4), 273-281.

Northey, S.A., Haque, N., Lovel, R., Cooksey, M.A., 2014. Evaluating the application of water footprint methods to primary metal production systems. Minerals Engineering 69, 65-80.

Noya, I., Aldea, X., Gasol, C.M., González-García, S., Amores, M.-J., Colón, J., Ponsá, S., Roman, I., Rubio, M.A., Casas, E., Moreira, M.-T., Boschmonart-Rives, J., 2016. Carbon and water footprint of pork supply chain in Catalonia: From feed to final products. Journal of Environmental Management 171, 133-143.

Noya, I., González-García, S., Bacanetti, J., Arroja, L., Moreira, M.-T., 2015. Comparative life cycle assessment of three representative feed cereals production in the Po Valley (Italy). Journal of Cleaner Production 99, 250-265.

Page, G., Ridoutt, B., Bellotti, B., 2012. Carbon and water footprint tradeoffs in fresh tomato production. Journal of Cleaner Production 32, 219-226.

Palhares, J.-C.-P., Pezzopane, J.-R.-M., 2015. Water footprint accounting and scarcity indicators of conventional and organic dairy production systems. Journal of Cleaner Production 93, 299-307.

Pan, L., Liu, P., Ma, L., Li, Z., 2012. A supply chain based assessment of water issues in the coal industry in China. Energy Policy 48, 93-102.

Payen, S., Basset-Mens, C., Perret, S., 2015. LCA of local and imported tomato: an energy and water trade-off. Journal of Cleaner Production 87, 139-148. 
Peña, C.A., Huijbregts, M.A.J., 2014. The Blue Water Footprint of Primary Copper Production in Northern Chile. Journal of Industrial Ecology 18(1), 49-58.

Pfister, S., Koehler, A., Hellweg, S., 2009. Assessing the environmental impacts of freshwater consumption in LCA. Environmental Science and Technology 43, 4098-4104.

Quinteiro, P., Dias, A.-C., Pina, L., Neto, B., Ridoutt, B.G., Arroja, L., 2014. Addressing the freshwater use of a Portuguese wine ('vinho verde') using different LCA methods. Journal of Cleaner Production 68, 46-55.

Ramírez, T., Meas, Y., Dannehl, D., Schuch, I., Miranda, L., Rocksch, T., Schmidt, U., 2015. Water and carbon footprint improvement for dried tomato value chain. Journal of Cleaner Production 104, 98-108.

Ranchod, N., Sheridan, C.M., Pint, N., Slatter, K., Harding, K.G., 2015. Assessing the blue-water footprint of an opencast platinum mine in South Africa. Water SA 41(2), 287-293.

Ridoutt, B.G., Eady, S.J., Sellahewa, J., Simons, L., Bektash, R., 2009. Water footprinting at the product brand level: case study and future challenges. Journal of Cleaner Production 17, 12281235.

Ridoutt, B.G., Juliano, P., Sanguansri, P., Sellahewa, J., 2010. The water footprint of food waste: case study of fresh mango in Australia. Journal of Cleaner Production 18, 1714-1721.

Ridoutt, B.G., Pfister, S., 2010. A revised approach to water footprinting to make transparent the impacts of consumption and production on global freshwater scarcity. Global Environmental Change 20 (1), 113-120.

Ridoutt, B.G., Sanguansri, P., Freer, M., Harper, G.S., 2012b. Water footprint of livestock: comparison of six geographically defined beef production systems. International Journal of Life Cycle Assessment 17, 165-175. 
Ridoutt, B.G., Sanguansri, P., Nolan, M., Marks, N., 2012a. Meat consumption and water scarcity: beware of generalizations. Journal of Cleaner Production 28, 127-133.

Rodriguez, C.I., Ruiz de Galarreta, V.A., Kruse, E.E., 2015. Analysis of water footprint of potato production in the pampean region of Argentina. Journal of Cleaner Production 90, 91-96.

Roibás, L., Elbehri, A., Hospido, A., 2015. Evaluating the sustainability of Ecuadorian bananas: Carbon footprint, water usage and wealth distribution along the supply chain. Sustainable Production and Consumption 2, 3-16.

Rudenko, I., Bekchanov, M., Djanibekov, U., Lamers, J.P.A., 2013. The added value of a water footprint approach: Micro- and macroeconomic analysis of cotton production, processing and export in water bound Uzbekistan. Global and Planetary Change 110, 143-151.

Ruini, L., Marino, M., Pignatelli, S., Laio, F., Ridolfi, L., 2013. Water footprint of a large-sized food company: The case of Barilla pasta production. Water Resources and Industry 1-2 , 7-24.

Sandelowski, M., Docherty, S., Emden, C., 1997. Focus on Qualitative Methods Qualitative Metasynthesis: Issues and Techniques. Research in Nursing and Health 20, 365-371.

Schäfer, F., Blanke, M., 2012. Farming and marketing system affects carbon and water footprint - a case study using Hokaido pumpkin. Journal of Cleaner Production 28, 113-119.

Stoessel, F., Juraske, R., Pfister, S., Hellweg, S., 2012. Life Cycle Inventory and Carbon and Water FoodPrint of Fruits and Vegetables: Application to a Swiss Retailer. Environmental Science and Technology 46, 3253-3262.

Su, M.-H., Huang, C.-H., Li, W.-Y., Tso, C.-T., Lur, H.-S., 2015. Water footprint analysis of bioethanol energy crops in Taiwan. Journal of Cleaner Production 88, 132-138. 
Suttayakul, P., H-Kittikun, A., Suksaroj, C., Mungkalasiri, J., Wisansuwannakorn, R., Musikavong, C., 2016. Water footprints of products of oil palm plantations and palm oil mills in Thailand. Science of the Total Environment 542, 521-529.

Tesco, 2014. Climate Change - Our Water Strategy. [pdf] Welwyn Garden City: Tesco. Available at: http://www.tescoplc.com/assets/files/cms/Resources/Environment/Our Water Strategy.pdf [Accessed 21 February 2016].

Tran, T., Da, G, Moreno-Santander, M.-A., Vélez-Hernández, G.-A., Giraldo-Toro, A., Piyachomkwan, K., Sriroth, K., Dufour, D., 2015. A comparison of energy use, water use and carbon footprint of cassava starch production in Thailand, Vietnam and Colombia. Resources, Conservation and Recycling 100, 31-40.

Tranfield, D., Denyer, D., Smart, P., 2003. Towards a Methodology for Developing Evidence-Informed Management Knowledge by Means of Systematic Review. British Journal of Management 14, 207-222.

Tsolakis, N.K., Keramydas, C.A., Toka, A.K., Aidonis, D.A., lakovou, E.T., 2014. Agrifood supply chain management: A comprehensive hierarchical decision-making framework and a critical taxonomy. Biosystems Engineering 120, 47-64.

Unilever, 2013. Progress Report 2012 - Unilever Sustainable Lining Plan. [pdf] Rotterdam and London: Unilever. Available at: https://www.unilever.com/Images/uslp-progress-report-2012fi tcm13-387367 tcm244-409862 en.pdf [Accessed 15 March 2016].

UN Water, 2009. The United Nations World Water Development Report 3 - Water in a Changing World. [pdf] Paris: United Nations Educational Scientific and Cultural Organization. Available at: http://webworld.unesco.org/water/wwap/wwdr/wwdr3/pdf/WWDR3 Water in a Changing W orld.pdf [Accessed 04 February 2016]. 
UN Water, 2014. The United Nations World Water Development Report 2014 - Water and Energy. [pdf] Paris: United Nations Educational Scientific and Cultural Organization. Available at: http://unesdoc.unesco.org/images/0022/002257/225741e.pdf [Accessed 04 February 2016].

van Hoof, G., Buyle, B., Kounina, A., Humbert, S., 2013. Life Cycle-based Water Assessment of a Hand Dishwashing Product: Opportunities and Limitations. Integrated Environmental Assessment and Management 9, 633-644.

van Oel, P.R., Hoekstra A.Y., 2012. Towards Quantification of the Water Footprint of Paper: A First Estimate of its Consumptive Component. Water Resources Management 26, 733-749.

Wackernagel, M., Rees, W., 1996. Our Ecological Footprint: Reducing Human Impact on the Earth. Gabriola Island: New Society Publishers.

Walmart, 2015. 2015 Global Responsibility Report - Opportunity, Sustainability, Community. [pdf] Bentonville: Walmart. $\quad$ Available at: https://cdn.corporate.walmart.com/c0/24/2383f0674d27823dcf7083e6fbc6/2015-globalresponsibility-report.pdf [Accessed 15 March 2016].

Wang, L., Ding, X., Wu, X., Yu, J., 2013. Textiles industrial water footprint: methodology and study. Journal of Scientific and Industrial Research 72, 710-715.

WBCSD, 2006. Facts and trends - water. [pdf] Geneva: World Business Council for Sustainable Development. Available at: http://www.unwater.org/downloads/Water facts and trends.pdf [Accessed 04 February 2016].

Zhang, Y., Wu, X.-Y., Wang, L.-L., Ding, X.-M., 2014. The industrial water footprint of zippers. Water Science and Technology 70(6), 1025-1031.

Zonderland-Thomassen, M.A., Ledgard, S.F., 2012. Water footprinting - A comparison of methods using New Zealand dairy farming as a case study. Agricultural Systems 110, 30-40. 